Result of land use planning and land administration (LULA) implementation in South Sumatra, East Kalimantan, Central Java and Papua

Aenunaim, Sudiyah Istichomah and Gamma Galudra 



\section{Result of Land Use Planning and Land Administration (LULA) Implementation in South Sumatra, East Kalimantan, Central Java and Papua}

Aenunaim, Sudiyah Istichomah and Gamma Galudra

Working Paper 283

\section{RESEARCH PROGRAM ON \\ Policies, \\ Institutions

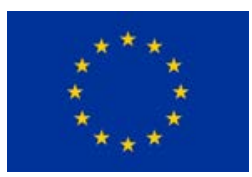

Ministry OF Foreign AFfairs of DENMARK

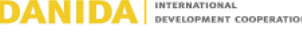

Australian Government Australian Centre for International Agricultural Research

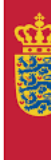

017 Deutsche Gesellschaft

Zusammenarbeit (GIZ) GmbH

RESEARCH

PROGRAM ON

Forests, Trees and

Agroforestry 


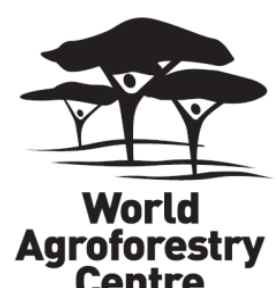

\section{Correct citation:}

Aenunaim, Istichomah S and Galudra G. 2018. Result of Land Use Planning and Land Administration (LULA) Implementation in South Sumatra, East Kalimantan, Central Java and Papua. Working Paper 283. Bogor, Indonesia: World Agroforestry Centre (ICRAF) Southeast Asia Regional Program. DOI:

http://dx.doi.org/10.5716/WP18010.PDF

Titles in the Working Paper Series aim to disseminate interim results on agroforestry research and practices and stimulate feedback from the scientific community. Other publication series from the World Agroforestry Centre include: Agroforestry Perspectives, Technical Manuals and Occasional Papers.

Published by the World Agroforestry Centre

Southeast Asia Regional Program

JL. CIFOR, Situ Gede, Sindang Barang, Bogor 16680

PO Box 161, Bogor 16001, Indonesia

Tel: +62 2518625415

Fax: +62 2518625416

Email: icraf-sea@cgiar.org; icraf-indonesia@cgiar.org

ICRAF Southeast Asia website: http://www.worldagroforestry.org/region/southeast-asia/

(C) World Agroforestry Centre 2018

Working paper no. 283

\section{Disclaimer and copyright}

The views expressed in this publication are those of the author(s) and not necessarily those of the World Agroforestry Centre. Articles appearing in this publication may be quoted or reproduced without charge, provided the source is acknowledged. All images remain the sole property of their source and may not be used for any purpose without written permission of the source. 


\section{About the authors}

Aenunaim joined World Agroforestry Centre - Southeast Asia (ICRAF -SEA) in mid-2014 as land governance research assistant, and in 2015 as Land Governance and Community Management Researcher until 2017. He also worked in the Lama-i, ParCimon and G-lamai projects. Currently is working as Environmental and Stakeholder Policy Specialist for Peatland, Restoration +, Strategic Environmental Assessment and One Map Initiative Project. Aenunaim graduated from Bogor Agricultural University majoring on Forest Resources Conservation. Contact: aenunaim@cgiar.org Sudiyah Istichomah was a Land Governance and Community Management research assistant for ICRAF Indonesia Program. Istichomah obtained her bachelor degree on Forest Management in Bogor Agricultural University. Before joining ICRAF, Istichomah worked as a program assistant for Integrated Water Resource Management - Negotiated Approach Program in Telapak Indonesia Bogor and was an international fellow researcher in World Forest Institute in Oregon, USA. Istichomah now works for RECOFTC - The Center for People and Forest Indonesia Country Program. Contact: nonette262@gmail.com

Gamma Galudra's main work interests is forest governance, common property rights and community-based forest management. He has been actively involved in forest governance, livelihoods and community-based forest management research for 17 years. During his period working with ICRAF, he was also leading several projects related to biodiversity, community-based forest management and low emission development policies since 2010, funded by ClimateWorks Foundation, Climate Land Use Alliance (CLUA) and Margareth A. Cargill Foundation. Currently, Mr. Galudra works for RECOFTC- The Center for People and Forests as the Director of Indonesia Country Program. Contact: gamma.galudra@recoftc.org 


\section{Abstract}

This paper presents results of Land Use Planning and Land Administration (LULA) in South Sumatra, Central Java, East Kalimantan and Papua. It discusses changes during planning and implementation, the policies related to spatial regulations, affecting people (public), problems and stakeholders' perspectives, and solutions to improve governance. The studies show that the most common problems in South Sumatra, East Kalimantan and Central Java are related to information and data management, coordination, and problems in spatial planning processes, and regulations and their implementation. On the other hand, the problems faced in Papua Province involving indigenous peoples appear in areas where there is still strong influence of customary practices and indigenous peoples' existence.

Keywords: Land Use Planning, Land Administration, Spatial Planning, indigenous people. 


\section{Acknowledgements}

This study has been supported and funded by the Research programs on Forests, Trees and Agroforestry (FTA) and Policies, Institutions, and Markets (PIM) of the Consultative Group on International Agricultural Research (CGIAR).

This research projects of the Participatory Monitoring by Civil Society of Land-use Planning for Lowemissions Development Strategies (PARCIMON) in Papua, funded by European Union; the Locallyappropriate Mitigation Actions in Indonesia (LAMA-I) in South Sumatra and Papua; funded by DANIDA, the Green Economy and Locally Appropriate Mitigation in Indonesia GE-LAMA-I (GELAMA-I) in Central Java and East Kalimantan, funded by GIZ; and also the Australian Centre for International Agricultural Research (ACIAR) for project in Vietnam. 


\section{Contents}

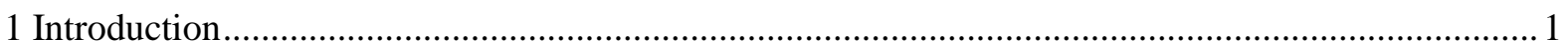

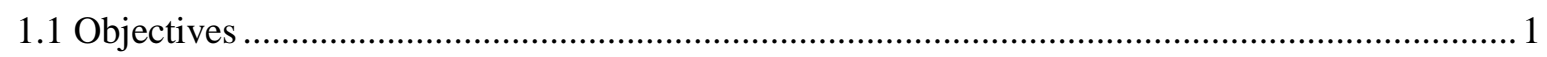

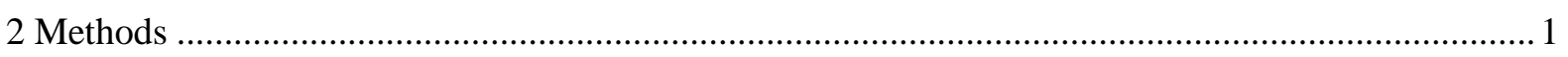

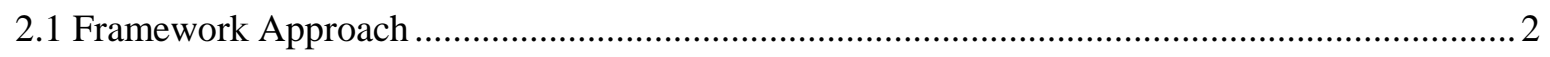

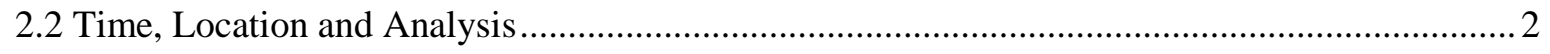

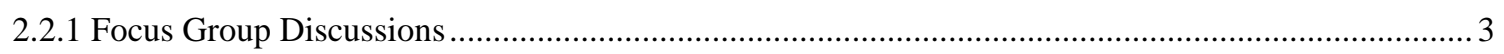

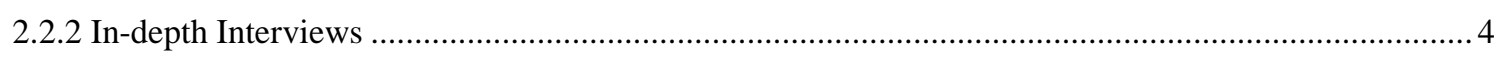

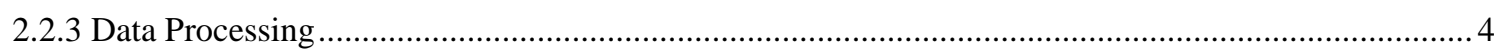

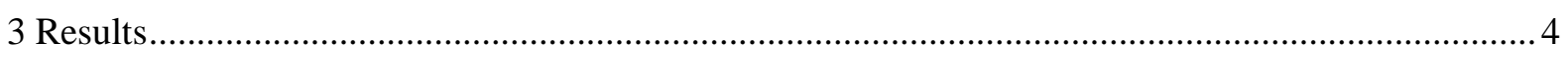

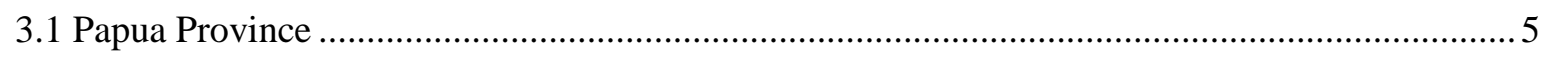

3.1.1 Similar Problems across 3 Districts in Papua............................................................................. 5

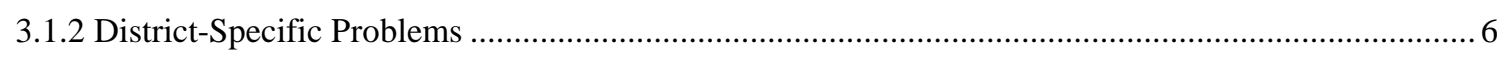

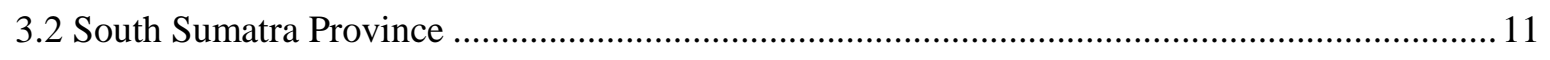

3.2.1 Similar Problems across 3 Districts in South Sumatra .................................................................. 12

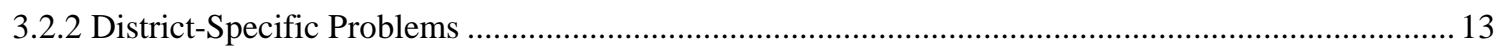

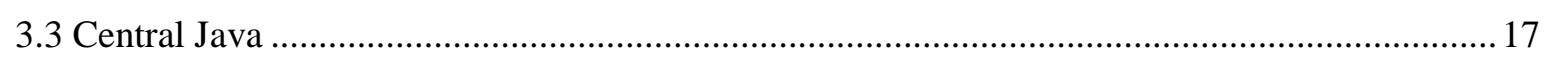

3.3.1 Similar Problems across 3 Districts in Central Java..................................................................... 18

3.3.2 District-Specific Problems in Central Java ................................................................................... 19

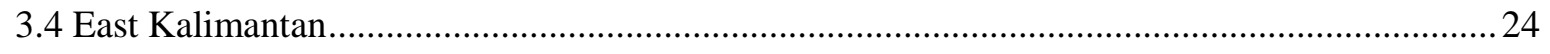

3.4.1 Similar Problems across 3 Districts in East Kalimantan ................................................................ 25

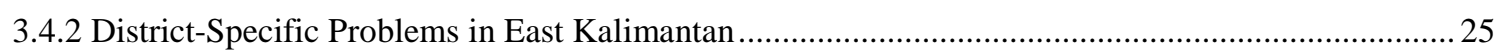

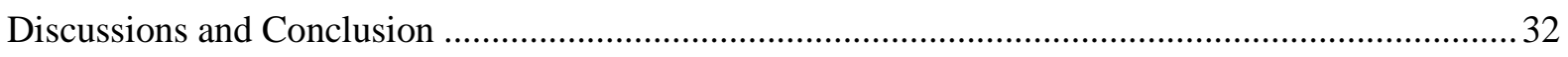

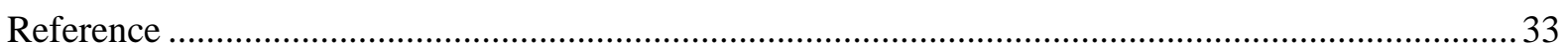




\section{List of Tables}

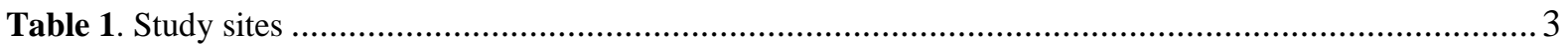

Table 2. Majority of LULA problems occurring in the 3 districts in Papua................................................. 5

Table 3. Details of land use and administration problems in Jayapura District based on stakeholders'

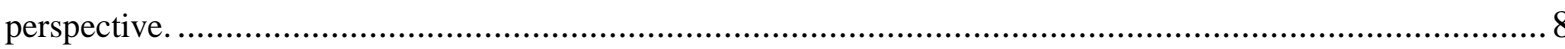

Table 4. Details of land use and administration problems in Merauke District based on stakeholders' perspective.

Table 5. Details of land use and administration problems in Jayawijaya District based on stakeholders' perspective.

Table 6. Majority of LULA problems occurring in the 3 districts in South Sumatra

Table 7. Details of land use and administration problems in Banyuasin District based on stakeholders' perspective.

Table 8. Details of land use and administration problems in Musi Banyuasin District based on stakeholders' perspective.

Table 9. Details of land use and administration problems in Musi Rawas District based on stakeholders'

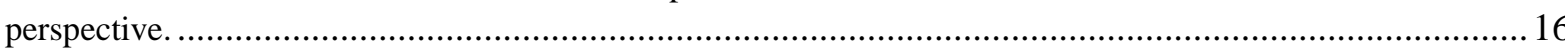

Table 10. Majority of LULA problems occurring in the 3 districts in Central Java. ....................................... 18

Table 11. Details of land use and administration problems in Banyumas District based on stakeholders' perspective.

Table 12. Details of land use and administration problems in Purbalingga District based on stakeholders' perspective.

Table 13. Details of land use and administration problems in Banjarnegara District based on stakeholders' perspective.

Table 14. Majority of LULA problems occurring in the 3 districts in East Kalimantan.

Table 15. Details of land use and administration problems in Paser District based on stakeholders' perspective.

Table 17. Details of land use and administration problems in East Kutai District based on stakeholders' perspective.

Table 18. Problem Exists in The Each Region

\section{List of Figure}

Figure 1. Framework Approach of Land Use Planning and Land Administration Assessment Process.............2

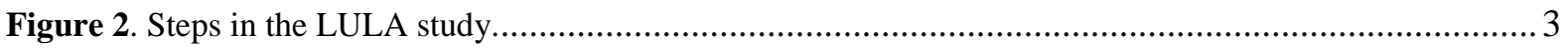

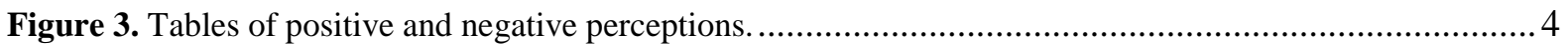




\section{Acronyms}

\begin{tabular}{ll} 
BKPRD & : Coordinating Spatial Planning Agency \\
BPMPT & $:$ Investment and Integrated Licensing Agency \\
BPN & $:$ National Land Agency \\
BPS & $:$ Statistic Indonesia \\
BUMN/D & $:$ State/Village-Owned Enterprise \\
CSR & $:$ Corporate Social Responsibility \\
FGD & $:$ Focus Group Discussion \\
FMU & $:$ Forest Management Unit \\
FPIC & $:$ Free, Prior and Informed Consent \\
HGU & $:$ Cultivation Rights \\
HR & $:$ Human Resources \\
IMB & $:$ Building Permit \\
IUPHHK & $:$ Business License for Timber Forest Product Utilization \\
LGAF & $:$ Land Governance and Assessment Framework \\
LULA & $:$ Land Use Planning and Land Administration \\
PERDA & $:$ Local Regulation \\
PERHUTANI & $:$ State Forest Company \\
PT. KAI & $:$ Indonesia Railway Company \\
PTSP & $:$ One System Integrated Services \\
RDTR & $:$ Detailed District Spatial Plan \\
RPJM & $:$ Medium-Term Development Plan \\
RPJP & $:$ Long-Term Development Plan \\
RTRW & $:$ Spatial Planning \\
& $:$ Local Government Work Unit \\
\hline
\end{tabular}




\section{Introduction}

\subsection{Objectives}

Land-use planning is the general term used for a branch of urban planning encompassing various disciplines which seek to manage and regulate land use in an efficient and ethical way (Young 1993), the systematic assessment of land and water potential (Metternicht 2017), thus preventing land-use conflicts resolution (Onyango and Gazzola 2011, Zhang et al 2012, Zhang and Fung 2013).

Governments apply land-use planning to manage the development of land within their jurisdictions (Mitchell, Buxton and Budge 2004). The government unit can plan for the needs of the community while safeguarding natural resources (Bernard and Levine 2014). Lands are evaluated and assessed to provide basis for decisions involving land disposition and utilization. This involves studies on the environmental effects on land use and its impact on the community. Thus, it also needs the land administration for its function that are divided into four components: juridical, regulatory, fiscal and information management. Like deeds for unregistered land, land administration document is a prima facie evidence of the ownership of land.

Indonesia's spatial plan (RTRW) is a direction for policy and strategy regarding spatial use that includes land space, oceanic space, and air space, including space within the earth as one united area, where humans and other creatures live, carry out activities and maintain a sustainable (Indonesian Act number 26 year 2007 regarding Spatial Planning). This document becomes the basis for spatial planning to create a space that safe, comfortable, productive and sustainable and to avoid conflicts. However, in terms of land administration, space is limited due to increasing need for land, along with growing populations and interests.

Land Use Planning and Land Administration (LULA) is a study on the land use changes from the perspectives of policies, planning and program and its impacts on spatial planning for the general public. This includes what will be changed from the expected goals, whether the land use plan can manage to avoid conflicts, and whether the land use plan supports the reduction of carbon emission. The LULA study was held in 4 provinces, South Sumatra, Central Java, East Kalimantan, and Papua. The LULA study in these 4 provinces tried to compile what happened in the region regarding land use and land administration, what problems the regions are dealing with based on the local stakeholders' perspectives and what solutions might be offered by stakeholders in such situations. A better understanding of the problem occurring will help the government as well as other stakeholders to solve the problem in the right way. 


\section{Methods}

\subsection{Framework Approach}

Figure 1 is the framework approach applied in the land use planning and land administration assessment process in this study. LULA approach refers to land uses according to local policymaker's perspective, in which the needs for lands should be relevant to the allocation, the lands should be allocated/designated/gazette by local governments based on their local spatial planning, and the lands should be relevant to the use. This has impacts on and changes the land use. General assumption is made out of the following three categories.

1. Land use changes should be based on the relevant regulations (Local Spatial Planning/RTRW).

2. Land use changes take place due to regulations but the use itself is not in line with the regulations (land grabbing, open access, etc.) (Feder and Feeny 2012).

3. Land use changes take place as they are subject to no regulations, e.g. prior to RTRW authorisation or land use is already in place).

This process is carried out by identifying problems in spatial planning and enabling factors that drive problems to get worse, the output of which should then be screened through criteria/indicator assessment based on the land use (land resources allocation policy and land governance practices) so as to identify any land use changes from the policymaker standpoint and practices.

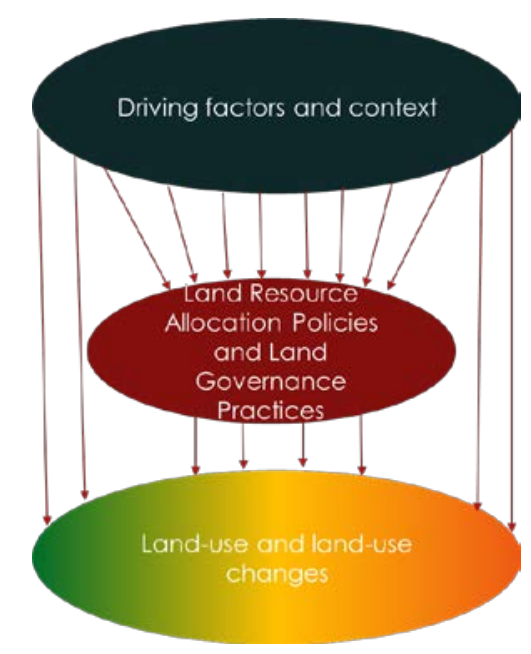

Figure 1. Framework Approach of Land Use Planning and Land Administration Assessment Process.

\subsection{Time, Location and Analysis}

This LULA study was conducted in 4 provinces, which are Central Java, East Kalimantan, South Sumatra, Papua, and 3 districts were selected for each province. Table 1 lists the districts in each province. 
Table 1. Study sites

\begin{tabular}{lllll}
\multirow{2}{*}{ Province } & \multicolumn{1}{c}{ South Sumatra } & \multicolumn{1}{c}{ Central Java } & \multicolumn{1}{c}{ East Kalimantan } & \multicolumn{1}{c}{ Papua } \\
\cline { 2 - 5 } District & Musi Banyuasin & Purbalingga & Paser & Jayapura \\
\cline { 2 - 5 } & Musi Rawas & Banyumas & Berau & Merauke \\
\cline { 2 - 5 } & Banyuasin & Banjarnegara & East Kutai & Jayawijaya \\
\hline
\end{tabular}

The first step in this study was a review of existing literature and documents, i.e. existing regulations both in national and regional levels. Then, based on the initial information from literature study, we conducted Focus Group Discussion (FGD) and in-depth interviews with local government agency representatives in the districts and other stakeholders.

FGDs were done to gather perceptions, aspirations and actual problems regarding spatial planning from the stakeholders, especially land-based local government agencies. Meanwhile, in-depth interviews were done to verify and obtain more information about the issues expressed in the FGDs and seek alternative solutions to the problems. The FGD and indepth interview for each district were done between 2015 and 2016. The following step is data processing, which consist of transcribing FGD and interview voice files, compiling data and information, sorting and grouping relevant data, and analysis of the data. The last step is writing a report of the results and discussion on the recommendation to better spatial planning and land administration in the districts.

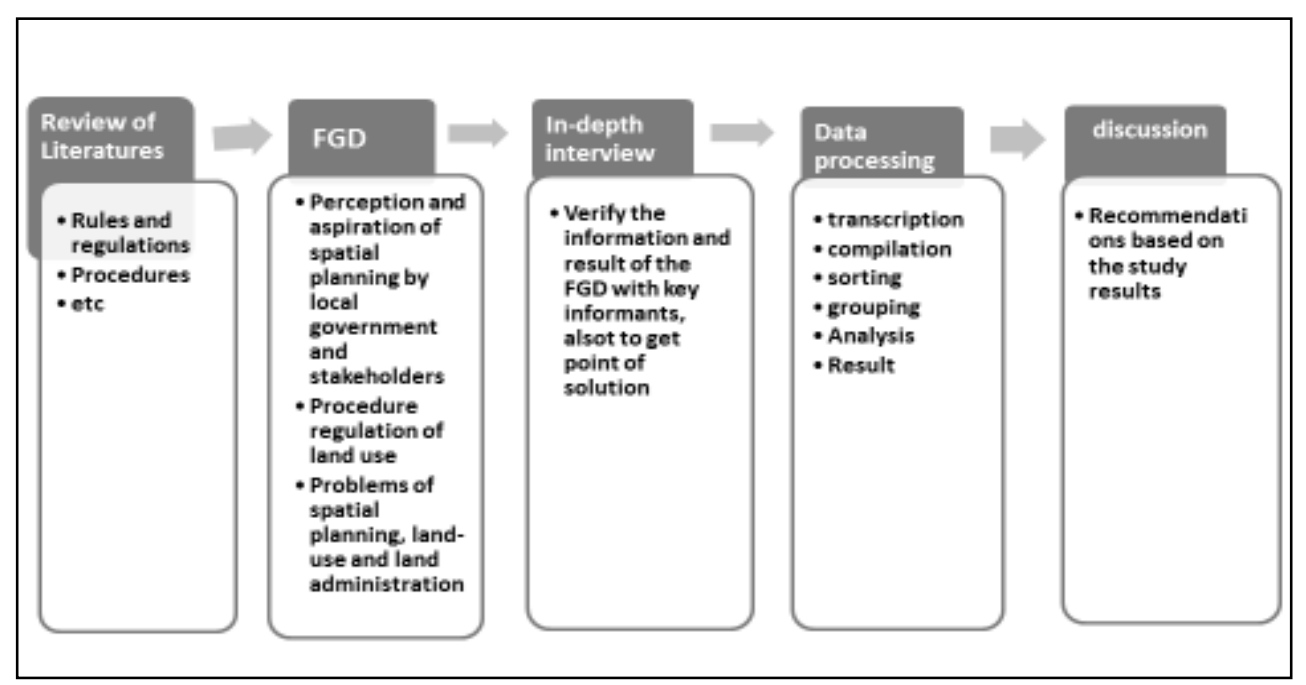

Figure 2. Steps in the LULA study.

\subsubsection{Focus Group Discussions}

The FGDs aim to obtain an overview of the knowledge and perceptions on the spatial planning processes, problems and ideal conditions of spatial planning according to participants. Participants are also expected to be able to categorize problems regarding spatial plan and land administration based on the Land Governance Assessment Framework (LGAF) key areas (Deininger, Selod and Burn 2012). The step by step process of the FGD is as follows. 
1. Inventory of FGD participants' perceptions on land use planning (and or spatial planning).

2. Grouping perceptions into positive or negative perceptions. The table used for this step is presented in Figure 2.

3. Clustering perceptions (negative) into five groups based on 5 key areas of LGAF. The participants categorized the negative perceptions which were also assumed to be the problems that might arise and faced by local stakeholders. The more negative perceptions there are in a key area group means the bigger the problem is in that particular group.

4. Develop problem findings. From the negative perceptions, participants then tried to dig deeper into problems related to spatial planning and land administration.

5. Discuss alternative solutions of the problems. All participants tried to find solutions to the problems.

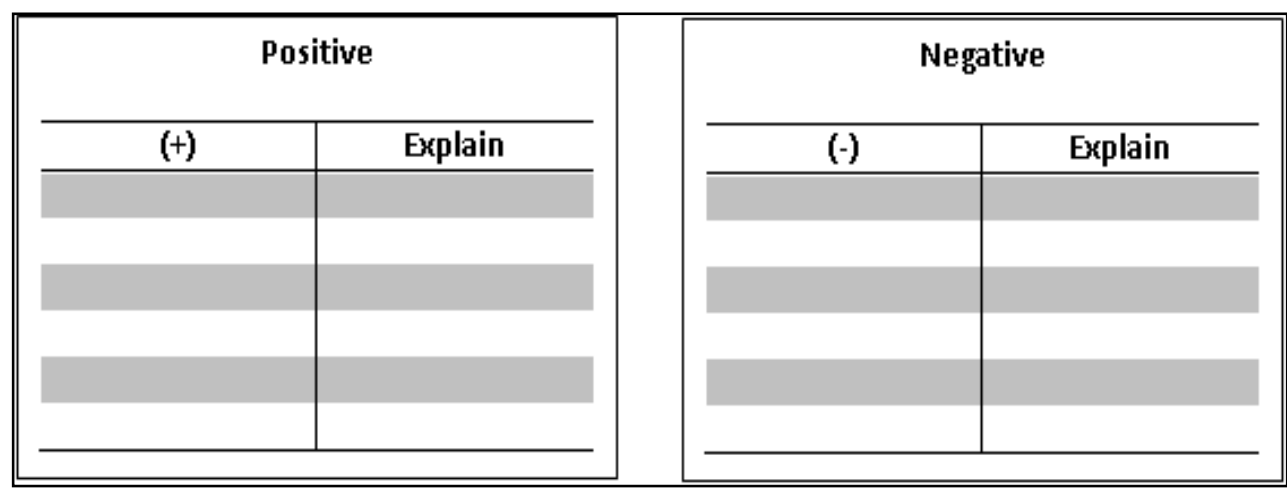

Figure 3. Tables of positive and negative perceptions.

\subsubsection{In-depth Interviews}

After the data collection in FGD, the next steps were interviews with key informants. The objective of in-depth interview was to verify the results of the FGD. The key informant is persons who are considered to know and understand the relevant issue, especially informants from local government who are in charge of land-based sectors.

\subsubsection{Data Processing}

Data processing was performed through descriptive qualitative methods (Lambert and Lambert 2012), which consists of the following steps: focus group discussion and interview voice files transcription, data and information compilation, relevant data sortation, grouping and data analysis. Data was then analyzed qualitatively.

\section{Results}

In the results section, the findings on spatial and land administration related problems from each province and district are presented, including description of their similarities and differences. 


\subsection{Papua Province}

Papua Province is Indonesia's easternmost province with a total area reaching about 316,553.07 km², which makes Papua the largest province in Indonesia. Papua is bordered by the Pacific Ocean in the north, the Arafuru Sea in the south, West Papua Province in the west, and Papua New Guinea in the East. Administratively Papua Province consists of 28 regencies and one municipality. The largest district in Papua Province is Merauke District with a total area 47,406.90 km² or about 14.98 percent of the total Papua Province area (Papua statistic 2017).

One thing that distinguishes Papua in Indonesia is the strong existence of indigenous peoples. Papua, with its many natural resources, faces great challenges in natural resources management, especially when positive and non-formal (customary) regulations do not complement one another and even at times conflicting.

In 2001, Indonesia enacted the Special Autonomy Law for Papua Province Number 21 Year 2001. Afterward the Papua provincial government enacted the Special Regional Regulation of Papua Province in 2008. Spatial plan in the Province is regulated by Provincial Regulation No. 23 year 2013 on Papua Province 2013-2033Spatial Plan, which is further clarified in detail for each district through the Detailed District Spatial Plan document (RDTR).

\subsubsection{Similar Problems across 3 Districts in Papua}

From the data collected in the three districts of the study sites, there are problems related to land use and land administration that occur in all districts, as shown in Table 2. This shoes that these problems are common in Papua Province, which pertain to indigenous peoples, lack of community involvement in spatial planning, lack of data and information management, and problems related to land use permits for private sectors.

Table 2. Majority of LULA problems occurring in the 3 districts in Papua.

\begin{tabular}{ll}
\multicolumn{1}{c}{ Categories } & \multicolumn{1}{c}{ Problems } \\
Indigenous peoples & $\begin{array}{l}\text { Problems related to Indigenous communities: acknowledgement, right } \\
\text { implementation, etc. }\end{array}$ \\
\hline Public involvement & Lack of public involvement in spatial planning processes \\
\hline Information and data & $\begin{array}{l}\text { Lack of good information and data management, including public information } \\
\text { disclosure }\end{array}$ \\
\hline Land use permit process & Problems related to land use permit process by private companies \\
\hline
\end{tabular}

Sources: interviews discussions and analysis

Problems related to indigenous peoples occurred in all 3 districts in the study sites. These problems are related to a variety of matters ranging from overlapping customary territories with other land uses, licenses granted to private companies, customary territory claims, and so on. One of the things believed to be a main cause is the unclear position of customary law in relation to positive law, as well as its recognition, including the recognition of indigenous communities and their territories. 
In addition, indigenous peoples live scattered over an area, at times in inaccessible areas, therefore information about government programs and policies often do not reach them. This situation can also potentially generate conflict, especially if these government programs apply in their customary territories. One example is what happens in forest area that overlaps with indigenous territories. The case in Jayapura District is one involving land occupation and encroachment in Cyclops Nature Reserve by the surrounding indigenous peoples. It is difficult for government to act as mediators to customary conflicts. Customary mechanisms are still used internally and often times there are variations among customs. A middle ground is needed to bridge the interests of customary law and positive law to properly resolve any conflict that occurs.

In addition, the customary territories have not been fully mapped properly and legal arrangements remain unclear. This also creates confusion when the customary land is used for non-customary purposes such as for investment or other developments. In some customary systems in Papua, there is no mechanism governing the release of customary land, only inheritance in one family or community group. Removal of customary land is usually accompanied by compensation. However, this can lead to a problem of recurring claims. Recurring claims of released customary land are usually made by the following generations, in which compensation is given to the father and then the child asks for additional compensation. This is a common problem in Papua and also regarded as an obstacle in incoming investment in the region due to the lack of clarity of land status. Licensing to land-based companies is still problematic.

Disclosure of public information related to land becomes an important point in the province of Papua, mainly in Merauke. There is limited data and information accessibility and disclosure. Information dissemination, especially regarding spatial planning, by Local Government is lacking. Due to limited budget, dissemination of District Spatial Plan (RTRWK) is done only to the district level with the excuse of difficult accessibility and lack of budget for information dissemination. Information on District Spatial Plan are not delivered to all villages, especially remote villages far from district centers.

\subsubsection{District-Specific Problems}

In addition to the problems observed across the three districts, specific problems were identified in each district in Papua.

\subsubsection{Jayapura}

Jayapura District, covering an area of $17,516.6 \mathrm{~km}^{2}$, is located near Jayapura City, the province capital situated along the district's eastern border. The population of Jayapura District in 2015 is 121,410 people, with a population density of 6.9 people per $\mathrm{km}^{2}$. In addition to settlements, the land in Jayapura district is used for agriculture with rice and sweet potato as the main commodities, as well as plantation with main commodities of cocoa, coconut and areca nut (BPS 2016). Forest area in Jayapura District covers approximately 1,353,404.92 hectares which is classified into protected 
forests, convertible production forests, production forests, limited production forests, nature reserve forest, tourism forests and forests for other uses. Utilization of timber forest products is done by companies (IUPHHK-HA) and by indigenous peoples under Permit for Timber Forest Utilization of Indigenous Peoples (IPKHMA).

The people in Jayapura District are still dominated by indigenous peoples with strong customary law. The indigenous peoples of Jayapura District are divided into 9 Customary Councils (DAS-Dewan Adat Suku), namely: Sentani-Buyakha, Imbi-Numbai, Oktim, Tepra, Djoukari, Elseng, Demutru, Moi and Yowari. As in other areas of Papua, challenges arise when both positive and customary laws are implemented. Lack of synergy leads to problems that are difficult to resolve.

For example, overlapping land use occurs in an area in the Cyclops Mountains that was designated as Nature Reserve forest. Currently there is overlapping land use with the community as well as with local government such as District office complex, Yowany Hospital, and Waibron landfill. In addition, communities are also laying claims in the nature reserve. One reason is the lack of community involvement in regulating the boundaries of the regions and therefore there is no agreement on the boundaries.

In Jayapura, investment-based companies have been around since the 1980s and have been growing to date. Large companies in Jayapura District, such as the oil palm plantation PT. Sinar Mas and the cocoa plantation PT. Purni Jaya. Other problems that arise in Jayapura for example is still lack of local government involvement in licensing process for land exploitation by large corporations. Company permits are issued by the central government, and meanwhile local government is not involved to provide recommendations. Permit process seem to be non-conforming its procedures.

Direct public implications include companies' failure to fulfil the rights of surrounding communities, particularly those associated with customary rights, as they are very specific and distinctive in Jayapura and Papua in general. In regards to these large companies, taxation proves to be an obstacle for local governments because local governments feel that they cannot intervene since business is conducted directly with the central government. Issues related to land-based companies are similar to those in other districts, as described in the previous sub-chapter.

In addition, there are many other land use and land administration problems in Jayapura District as presented in Table 3. These issues are summarized from the results of discussions and interviews with stakeholders in Jayapura District. 
Table 3. Details of land use and administration problems in Jayapura District based on stakeholders' perspective.

\begin{tabular}{|c|c|c|}
\hline Categories & Problems & Details of problems in Jayapura \\
\hline $\begin{array}{l}\text { Land } \\
\text { administration }\end{array}$ & $\begin{array}{l}\text { Unclear land administration } \\
\text { (including land certification, } \\
\text { land ownership data, etc.) }\end{array}$ & $\begin{array}{l}\text { There is no valid data on land ownership, including } \\
\text { customary land, in National Land Agency }\end{array}$ \\
\hline Illegal land use & Illegal land use & Illegal gold mining activities inside the nature reserve forest \\
\hline \multirow[t]{3}{*}{$\begin{array}{l}\text { Information and } \\
\text { data }\end{array}$} & \multirow[t]{3}{*}{$\begin{array}{l}\text { Poor information and data } \\
\text { management }\end{array}$} & $\begin{array}{l}\text { Lack of transparency from private companies concerning } \\
\text { public information. }\end{array}$ \\
\hline & & $\begin{array}{l}\text { Lack of information dissemination regarding spatial planning } \\
\text { policies to the public }\end{array}$ \\
\hline & & Lack of data synchronicity among government agencies \\
\hline $\begin{array}{l}\text { Policy and } \\
\text { regulations }\end{array}$ & $\begin{array}{l}\text { Lack of synergy } \\
\text { (inconsistency) among } \\
\text { regulations and policies }\end{array}$ & $\begin{array}{l}\text { District Spatial Plan (RTRWK) is not synchronized with } \\
\text { district development plan }\end{array}$ \\
\hline $\begin{array}{l}\text { Conflict } \\
\text { management }\end{array}$ & Ineffective conflict resolution & Unresolved land conflicts \\
\hline \multirow[t]{2}{*}{ Coordination } & $\begin{array}{l}\text { Poor cross-sectoral } \\
\text { coordination }\end{array}$ & $\begin{array}{l}\text { Different land use permit mechanisms among district } \\
\text { government work units (SKPD) }\end{array}$ \\
\hline & $\begin{array}{l}\text { Poor interlevel government } \\
\text { coordination }\end{array}$ & $\begin{array}{l}\text { Some land use permit processes do not involve local } \\
\text { governments enough but instead directly engage the central } \\
\text { government. }\end{array}$ \\
\hline Resources & $\begin{array}{l}\text { Lack of resources for } \\
\text { government, such as budget } \\
\text { allocation, HR, etc. }\end{array}$ & $\begin{array}{l}\text { There is no flexible space utilization monitoring system (that } \\
\text { applies GIS) }\end{array}$ \\
\hline \multirow[t]{3}{*}{$\begin{array}{l}\text { Land use permit } \\
\text { process }\end{array}$} & \multirow[t]{3}{*}{$\begin{array}{l}\text { Problems related to land use } \\
\text { permit process by private } \\
\text { companies }\end{array}$} & $\begin{array}{l}\text { Companies also tend to take shortcuts in licensing processes } \\
\text { by bypassing local government and instead directly } \\
\text { coordinating with central government. }\end{array}$ \\
\hline & & $\begin{array}{l}\text { Small-scale land-based ventures with strong relationship with } \\
\text { local communities does not seem to undergo permit } \\
\text { processes. For example: Sawmills operate without permits } \\
\text { from the Forestry Agency. }\end{array}$ \\
\hline & & $\begin{array}{l}\text { IPKHMA are usually backed by timber barons (immigrants) } \\
\text { to secure their licenses and businesses. }\end{array}$ \\
\hline \multirow[t]{2}{*}{ Maps } & \multirow{2}{*}{$\begin{array}{l}\text { Lack of clarity in mapping } \\
\text { process }\end{array}$} & Different map scales between province and districts \\
\hline & & $\begin{array}{l}\text { There is no agreement on the Cyclops Nature Reserve forest } \\
\text { boundary with the local communities }\end{array}$ \\
\hline \multirow[t]{5}{*}{$\begin{array}{l}\text { Indigenous } \\
\text { people }\end{array}$} & \multirow[t]{5}{*}{ Recognition } & $\begin{array}{l}\text { Overlapping customary land within Cyclops Nature Reserve } \\
\text { area }\end{array}$ \\
\hline & & Unclear knowledge of customary territory boundaries \\
\hline & & $\begin{array}{l}\text { Internal community conflict about land use permit } \\
\text { mechanism under customary laws }\end{array}$ \\
\hline & & $\begin{array}{l}\text { The local government cannot intervene in customary } \\
\text { mechanism }\end{array}$ \\
\hline & & $\begin{array}{l}\text { Land use permits over customary land are not in accordance } \\
\text { with District Spatial Plan }\end{array}$ \\
\hline Tax & Poor tax management & $\begin{array}{l}\text { Local government cannot intervene with high taxes for big } \\
\text { companies because of central government tax regulations. }\end{array}$ \\
\hline $\begin{array}{l}\text { Public } \\
\text { involvement }\end{array}$ & $\begin{array}{l}\text { Lack of community } \\
\text { participation }\end{array}$ & $\begin{array}{l}\text { Lack of local community engagement in establishing } \\
\text { boundaries for Cyclops Nature Reserve. }\end{array}$ \\
\hline Conflicts & $\begin{array}{l}\text { Conflict between business } \\
\text { concessions and communities }\end{array}$ & $\begin{array}{l}\text { Companies do not fulfil communities' rights, such as } \\
\text { compensation for their land. }\end{array}$ \\
\hline
\end{tabular}




\begin{tabular}{ll} 
& \multicolumn{1}{c}{$\begin{array}{l}\text { Companies often use local communities to smooth their } \\
\text { permits process. }\end{array}$} \\
\cline { 3 - 3 } $\begin{array}{l}\text { Overlapping land } \begin{array}{l}\text { Internal conflicts between communities because of different } \\
\text { opinions about compensation fee. }\end{array} \\
\text { use }\end{array}$ & $\begin{array}{l}\text { Land claims and encroachment inside the Cyclops Nature } \\
\text { Reserve. Overlapping land use with local government offices } \\
\text { and public facilities. }\end{array}$ \\
\cline { 2 - 2 } & $\begin{array}{l}\text { Overlapping land use between companies (mining } \\
\text { companies) }\end{array}$ \\
\cline { 2 - 3 } & $\begin{array}{l}\text { Overlapping land use permits between local, provincial and } \\
\text { national authorities }\end{array}$ \\
\hline
\end{tabular}

Sources: interviews and discussions

\subsubsection{Merauke}

Merauke is the easternmost district in Indonesia and the largest district in Papua Province, covering approximately $14.67 \%$ of the total province area or $46,791.63 \mathrm{~km}^{2}$. Merauke District population has grown annually, and in 2016 the population of Merauke reached 220,006 inhabitants with a population density of 4.7 per $\mathrm{km}^{2}$.

Merauke District is mostly lowland. Merauke is the largest rice producer in Papua Province with production in 2016 of 190,496.36 tons. In the plantation sector, coconut is the main commodity grown all over the sub-district over an area of 6,726 hectares. However, the plantation covering the largest area is palm oil, with 38,149.10 ha plantations located in Muting, Ulilin and several areas in Ngguti. The total area of forest in Merauke Regency is 4,812,903 ha, which is dominated by nature reserve/conservation area (1,450,998 ha), convertible production forest (1,311,254 ha) and production forest $(1,010,279 \mathrm{ha})$.

Table 4. Details of land use and administration problems in Merauke District based on stakeholders' perspective.

\begin{tabular}{|c|c|c|}
\hline Categories & Problems & Merauke \\
\hline \multirow{3}{*}{$\begin{array}{l}\text { Information and } \\
\text { data }\end{array}$} & \multirow[t]{3}{*}{ Information and data management } & Lack of information of spatial plan and land use \\
\hline & & $\begin{array}{l}\text { Lack of socialization to the public about spatial plan. } \\
\text { Socialization is done only to the sub-district level }\end{array}$ \\
\hline & & $\begin{array}{l}\text { Information is difficult to reach to the field level, as in } \\
\text { villages in the remote area. }\end{array}$ \\
\hline Resources & $\begin{array}{l}\text { Lack of resources for government, } \\
\text { including budget, HR, etc. }\end{array}$ & $\begin{array}{l}\text { Lack of budget from local government expenditure (APBD) } \\
\text { for spatial planning process }\end{array}$ \\
\hline \multirow[t]{2}{*}{$\begin{array}{l}\text { Land use permit } \\
\text { process }\end{array}$} & \multirow[t]{2}{*}{$\begin{array}{l}\text { Problems related to land use permit } \\
\text { process by private companies }\end{array}$} & $\begin{array}{l}\text { Investment and integrated licensing agencies are not } \\
\text { working optimally }\end{array}$ \\
\hline & & License violation by the private companies \\
\hline \multirow[t]{2}{*}{$\begin{array}{l}\text { Indigenous } \\
\text { peoples }\end{array}$} & \multirow[t]{2}{*}{$\begin{array}{l}\text { Problems related to indigenous } \\
\text { people }\end{array}$} & $\begin{array}{l}\text { Scattered distribution of indigenous territories makes it } \\
\text { difficult to involve all of communities in many programs, } \\
\text { such as spatial plan socialization }\end{array}$ \\
\hline & & Low education level of the majority of the communities \\
\hline
\end{tabular}




\begin{tabular}{lll}
$\begin{array}{ll}\text { Land use } \\
\text { planning }\end{array}$ & Problems related to spatial plan & Spatial plan is not in accordance with land potential \\
\hline Regulation & $\begin{array}{l}\text { Conflict between communities and } \\
\text { companies }\end{array}$ & Problems with implementation of spatial plan regulation \\
\hline Conflict & Companies' activities are threatening local livelihoods \\
\cline { 3 - 3 } & Lack of transparency in investor-community partnership \\
\cline { 3 - 3 } & Land use overlap & Onerlapping land use \\
\hline Overlapping & Latequate land compensation for communities \\
\hline
\end{tabular}

Sources: interviews and discussions

\subsubsection{Jayawijaya}

Jayawijaya District, with its capital Wamena, is situated surrounded by mountains in a valley known as Baliem Valley. Geographically, Jayawijaya is located the Central Mountain Range of Papua alongside the Tolikara, Puncak Jaya, Puncak, Nduga, Yalimo, Lanny Jaya, Central Mamberamo, Pegunungan Bintang and Yahukimo Districts. Jayawijaya District sits at an elevation of 1550 meters above sea level. Today, transportation to Jayawijaya still relies on air routes. The population of Jayawijaya is 210.229 people with a density of 24.74 people per $\mathrm{km}^{2}$ as of 2016 . Indigenous peoples are the majority in Baliem Valley. Many migrants from different regions live mainly in the city of Wamena.

The largest agricultural land use in Jayawijaya is for sweet potato cultivation. This commodity is the staple food in the region. In 2016, sweet potato harvest reached 72,807 ha. Meanwhile, coffee is the main plantation crop is which is widely known as Wamena Coffee. The main settlements and economic region activities are centered in Wamena, whereas community settlements are spread over 40 districts in the Baliem Valley. Forest area of in Jayawijaya District covers 168,025.9 ha consisting of production forest (4,992.63 ha), convertible production forest (45,077,507 ha), protected forest (11,557.06 ha), conservation forest (52.004,93 ha), as well as other use areas $(54,393,654 \mathrm{ha})$.

Baliem Valley has great potential in vast and fertile land. However, it is said that there are still large areas of open, unused yet economically potential land. Unclear customary regulations, especially those regarding use of customary land as well as frequent repeated claims of community compensation, make it difficult for investments to enter the area. Synergy is needed to harmonize customary rules with positive laws. 
Table 5. Details of land use and administration problems in Jayawijaya District based on stakeholders' perspective.

\begin{tabular}{|c|c|c|}
\hline Categories & Problems & Jayawijaya \\
\hline Illegal use & $\begin{array}{l}\text { Illegal land-use practices (including } \\
\text { land encroachment and land } \\
\text { occupation) }\end{array}$ & Encroachment inside Lorentz National Park \\
\hline \multirow[t]{2}{*}{$\begin{array}{l}\text { Data and } \\
\text { information }\end{array}$} & \multirow[t]{2}{*}{ Information and data management } & $\begin{array}{l}\text { Lack of socialization to the public about spatial plan. } \\
\text { Socialization is done only to the sub-district level }\end{array}$ \\
\hline & & Lack of government transparency to the public \\
\hline $\begin{array}{l}\text { Program } \\
\text { sustainability }\end{array}$ & $\begin{array}{l}\text { Program sustainability is not } \\
\text { guaranteed }\end{array}$ & $\begin{array}{l}\text { Regulation changes following changes in } \\
\text { leadership/officials }\end{array}$ \\
\hline Land conversion & $\begin{array}{l}\text { Land conversion not in accordance } \\
\text { with land designation }\end{array}$ & Land conversion of productive farmlands to buildings \\
\hline Coordination & Poor cross-sectoral coordination & $\begin{array}{l}\text { Poor coordination by Regional Spatial Planning Agency as } \\
\text { coordination forum }\end{array}$ \\
\hline \multirow[t]{2}{*}{$\begin{array}{l}\text { Land use permit } \\
\text { process }\end{array}$} & \multirow{2}{*}{$\begin{array}{l}\text { Problems related to land use } \\
\text { permit process by private } \\
\text { companies }\end{array}$} & $\begin{array}{l}\text { In the district capital, people often build without reference to } \\
\text { spatial plan }\end{array}$ \\
\hline & & $\begin{array}{l}\text { One Stop Integrated Service Agency is not given all the } \\
\text { mandates to manage all land use permit processes }\end{array}$ \\
\hline \multirow[t]{2}{*}{$\begin{array}{l}\text { Indigenous } \\
\text { communities }\end{array}$} & \multirow[t]{2}{*}{ Problems on indigenous peoples } & $\begin{array}{l}\text { There are no positive regulations about } \\
\text { indigenous/customary regulation }\end{array}$ \\
\hline & & $\begin{array}{l}\text { It is difficult for local government to manage land under } \\
\text { customary status }\end{array}$ \\
\hline \multirow{3}{*}{$\begin{array}{l}\text { Spatial plan } \\
\text { process }\end{array}$} & \multirow[t]{3}{*}{ Problems on spatial planning } & Large areas of open land \\
\hline & & Poor city spatial plan \\
\hline & & $\begin{array}{l}\text { Spatial plan process is time-consuming and done not in } \\
\text { accordance with actual conditions }\end{array}$ \\
\hline \multirow[t]{2}{*}{ Implementation } & \multirow[t]{2}{*}{ Poor implementation of regulations } & Law enforcement/regulation is not yet fully implemented \\
\hline & & Lack of enforcement of sanctions against spatial violations \\
\hline $\begin{array}{l}\text { Public } \\
\text { involvement }\end{array}$ & Lack of public engagement & Lack of public engagement in spatial planning \\
\hline Detail spatial plan & RDTR related issues & Detailed spatial plan is not ready yet \\
\hline
\end{tabular}

Sources: interviews and discussions

\subsection{South Sumatra Province}

South Sumatra covers an area of 87,421.17 km². With its development and expansion, South Sumatra is divided into 13 districts and 4 municipalities. South Sumatra is a portrait of an area rich in natural resources that attracts a lot of investment into the province - especially the rapid development of oil palm plantations and mines - and the numerous resulting problems and challenges faced by local governments in managing the province. South Sumatra Province, located in the southern part of the island of Sumatra, has abundant natural resources and attracts investments into the province. Major capital investment that makes up the most of the plantation sector is oil palm plantation and mining sectors. Investments that require land alterations continue to grow along with the increasing demand for regional development. 
At the provincial level, South Sumatra Provincial Regulation Number 14 was issued in 2006 concerning 2005-2019 Provincial Spatial Plan (RTRWP). At the district level, Banyuasin District issued its Local Regulation on Banyuasin District Spatial Plan (RTRWK) No. 28 in 2012, Musi Banyuasin District Spatial Plan No. 4 in 2012, and Musi Rawas District Spatial Plan No. 2 in 2013. District Spatial Plan provides reference in creating regional development plans such as Long-Term or Medium-Term District Development Plans (RPJPD and RPJMD), local land use and development, investment sites within a district, Detailed Spatial Plan (RDTR), basis for controlling land use, and as a reference in the implementation of land administration.

\subsubsection{Similar Problems across 3 Districts in South Sumatra}

The main problems occurring in South Sumatra are poor cross-sectoral and inter level (vertical) government coordination, land conversion not in accordance with its allocation, problems related to land use permit process by private sector, map issues and boundary arrangement, and poor implementation of regulation layout at the site level.

Table 6. Majority of LULA problems occurring in the 3 districts in South Sumatra

\section{Categories}

\begin{tabular}{ll} 
Land conversion & Land conversion not in accordance with its designation \\
\hline Coordination & Poor cross-sectoral and inter level (vertical) government coordination \\
\hline $\begin{array}{l}\text { Land use permit } \\
\text { process }\end{array}$ & Problems related to land use permit process by private companies \\
\hline Maps & Problems related to maps, including boundary arrangements \\
\hline Implementation & Poor regulation implementation \\
\hline
\end{tabular}

Sources: interviews, discussions and analysis

Numerous problems stem from lack of clear land regulations and poor enforcement. The problem in the three districts is the lack of inter-sectoral coordination, in the case of land under the authority of a number of institutions/agencies, inter departmental coordination and whether the authority of each agency has been clearly defined to avoid overlapping authority. Coordination between the local government agencies are lacking and therefore increases the likelihood of problems in cross-sectoral policies.

Coordination is also closely linked to information and data on which policies in each agency are based on. Although the main problem is not mentioned and tend to be hidden by other issues, some mentioned a lack of transparency among government agencies and ownership data among agencies do not have the same basis. This trigger decisions being made that affect land use overlaps and land conflicts.

One example takes place in Musi Rawas with BPN-certified land in forest areas. BPN itself can only issue certification lands outside of forest areas. The lack of cross-checked information and 
coordination is one of the drivers. In addition, there were many overlapping licenses as frequently mentioned by the parties.

As a growing province with a lot of investment in its region, South Sumatra has many land-based company concessions, namely oil palm plantations, mines, plantations, etc. Problems that were often mentioned are those related to both concession permit and production process and implementation. Overlapping concession area among companies, conflicts with communities around concessions and violations by concessions are some of the problems frequently observed. Poor conflict management makes social problems become prolonged and difficult to resolve.

Spatial Plan as a development guideline has yet to become a reference for all spatial and land related development. All documents in planned programs should refer to the spatial plan as a function of the spatial plan itself.

\subsubsection{District-Specific Problems}

\subsubsection{Banyuasin}

Banyuasin District covers an area of $11,832.99 \mathrm{~km}^{2}$ in which $80 \%$ of its topography is flat land in the form of tidal swamp, swamps, and dry land. Banyuasin District population in 2015 is 811,501 people, with a population density of 68.6 people per $\mathrm{km}^{2}$. Banyuasin is a transmigration destination since the New Order era.

Agriculture is the leading sector in Banyuasin, accounting for 34.49\% of the district GDP in 2014. The largest land use is for plantations covering 287,749 ha and rice fields 226,418 ha. Oil palm plantations in Banyuasin use the most extensive land of about 150,041 ha, followed by rubber 90,774 ha, coconut 47,285 ha, and coffee 5,092 ha.

A number of villages are located within forest areas in Banyuasin, Musi Banyuasin and Musi Rawas Districts, and to this day these villages have not been released or enclaved. It is said that this process is currently ongoing. Whereas in urban areas, green open spaces are prone to conflicts of interest between the need for public space and business interests. The local government is expected to be stricter in regulating this issue.

Table 7. Details of land use and administration problems in Banyuasin District based on stakeholders' perspective.

\begin{tabular}{lll}
\multicolumn{1}{c}{ Categories } & \multicolumn{1}{c}{ Problems } \\
Land conversion & $\begin{array}{l}\text { Land conversion due to } \\
\text { market trends, etc. }\end{array}$ & $\begin{array}{l}\text { Trends of land conversion from forests to oil palm } \\
\text { plantations }\end{array}$ \\
\cline { 2 - 2 } & $\begin{array}{l}\text { Settlement business developments affect land } \\
\text { conversion }\end{array}$ \\
\hline Coordination & $\begin{array}{l}\text { Poor cross-sectoral } \\
\text { coordination }\end{array}$ & $\begin{array}{l}\text { Sometimes BAPPEDA - the agency in charge of } \\
\text { spatial planning - is not involved when spatial issues } \\
\text { occur on the ground }\end{array}$ \\
\cline { 2 - 3 } & $\begin{array}{l}\text { Poor coordination between } \\
\text { central and local }\end{array}$ & $\begin{array}{l}\text { Lack of local government engagement in forest } \\
\text { management in the area }\end{array}$ \\
\hline
\end{tabular}




\begin{tabular}{lll} 
& governments & No local involvement in land use change management \\
\hline Environmental problems & Environmental problems & $\begin{array}{l}\text { Problems related to landfill site is a major issue in the } \\
\text { district }\end{array}$ \\
\hline Land use permit process & $\begin{array}{l}\text { Problems related to land use } \\
\text { permit process by private } \\
\text { companies }\end{array}$ & $\begin{array}{l}\text { Lack of coordination between private sectors and } \\
\text { BAPPEDA or other local government agencies }\end{array}$ \\
\cline { 3 - 3 } & $\begin{array}{l}\text { A number of land use permit practices are not in } \\
\text { accordance with existing spatial regulations }\end{array}$ \\
\cline { 3 - 3 } & $\begin{array}{l}\text { Problems related to maps, } \\
\text { including boundaries }\end{array}$ & $\begin{array}{l}\text { Private companies tend to take shortcuts in business } \\
\text { license processes }\end{array}$ \\
\cline { 2 - 3 } Maps & $\begin{array}{l}\text { Lack of good maps as general reference } \\
\text { Problems on spatial plan } \\
\text { processes }\end{array}$ & $\begin{array}{l}\text { Potential for regional expansion due to regional } \\
\text { development gaps }\end{array}$ \\
\hline Spatial plan & $\begin{array}{l}\text { Regulations are not fully } \\
\text { enforced }\end{array}$ & $\begin{array}{l}\text { Certain actors attempt to take shortcuts in permit } \\
\text { processes, such as those who ask for land in protected } \\
\text { forest areas directly to the central government. }\end{array}$ \\
\hline Implementation & &
\end{tabular}

Sources: interviews and discussions

\subsubsection{Musi Banyuasin}

Musi Banyuasin District covers an area of 14,265.96 km² or about 15 percent of South Sumatra

Province. Musi Banyuasin is a swamp area traversed by large and small rivers, such as Musi, Leko

River, Batang Hari, and Banyuasin Rivers. The district also contains many small lakes. The district is home to an estimated population of 620,738 people in 2016, with a density of about 43 people per $\mathrm{km}^{2}$. The largest utilization of land in Musi Banyuasin is for company or community-managed plantations. The area's major plantation commodities are oil palm and rubber.

Table 8. Details of land use and administration problems in Musi Banyuasin District based on stakeholders' perspective.

\begin{tabular}{|c|c|c|}
\hline Categories & Problems & Musi Banyuasin \\
\hline \multirow[t]{6}{*}{ Land administration } & \multirow{6}{*}{$\begin{array}{l}\text { Unclear land administration } \\
\text { (including land certification, land } \\
\text { ownership data, etc.) }\end{array}$} & Most people do not have land certificates \\
\hline & & $\begin{array}{l}\text { Poor village-level land administration, archiving and } \\
\text { documentation }\end{array}$ \\
\hline & & Forest land swaps \\
\hline & & $\begin{array}{l}\text { A number of villages and settlements are located inside } \\
\text { forest areas with unclear status }\end{array}$ \\
\hline & & $\begin{array}{l}\text { There is an oil palm plantation in South Sumatra with } \\
\text { license from Jambi }\end{array}$ \\
\hline & & $\begin{array}{l}\text { Uncontrolled public swaps of areas under unclear land } \\
\text { status }\end{array}$ \\
\hline Illegal land use & Illegal land use & Forest encroachment by communities \\
\hline \multirow[t]{3}{*}{ Conflict } & \multirow[t]{3}{*}{ Ineffective conflict management } & Numerous community claims placed on forest area \\
\hline & & $\begin{array}{l}\text { Land conflict between communities and plantation } \\
\text { companies }\end{array}$ \\
\hline & & $\begin{array}{l}\text { Although companies are in the middle of conflict } \\
\text { resolution process, they still carry out their business as } \\
\text { usual. This triggers more conflicts }\end{array}$ \\
\hline
\end{tabular}




\begin{tabular}{|c|c|c|}
\hline \multirow[t]{2}{*}{ Information and data } & \multirow{2}{*}{$\begin{array}{l}\text { Lack of information and data } \\
\text { management }\end{array}$} & Lack of transparency in land use permits process \\
\hline & & $\begin{array}{l}\text { Government in the field, such as village government, } \\
\text { does not fully understand about the land use in their } \\
\text { area }\end{array}$ \\
\hline \multirow[t]{2}{*}{ Land conversion } & \multirow[t]{2}{*}{$\begin{array}{l}\text { Land conversion due to market } \\
\text { trends, etc. }\end{array}$} & $\begin{array}{l}\text { Trends of land conversion from forests to oil palm } \\
\text { plantations }\end{array}$ \\
\hline & & $\begin{array}{l}\text { Mass land conversion from rubber plantation to other } \\
\text { land use types }\end{array}$ \\
\hline \multirow[t]{2}{*}{ Coordination } & Poor cross-sectoral coordination & $\begin{array}{l}\text { Complex problems in forest areas are handled by } \\
\text { forestry agency only, lack of involvement of other } \\
\text { government agencies }\end{array}$ \\
\hline & $\begin{array}{l}\text { Poor coordination between } \\
\text { central and local governments }\end{array}$ & $\begin{array}{l}\text { Law } 23 / 2014 \text { has led to the transfer of district } \\
\text { authorities to province in some sectors, including } \\
\text { forestry }\end{array}$ \\
\hline \multirow[t]{2}{*}{ Resources } & \multirow{2}{*}{$\begin{array}{l}\text { Lack of government resources } \\
\text { (including lack of budget, human } \\
\text { resources, etc.) }\end{array}$} & $\begin{array}{l}\text { No development in BPSDM (Human resource } \\
\text { development agency) }\end{array}$ \\
\hline & & $\begin{array}{l}\text { Local governments are unresponsive to local potential } \\
\text { development ideas }\end{array}$ \\
\hline \multirow[t]{2}{*}{ Land use permit process } & \multirow{2}{*}{$\begin{array}{l}\text { Problems related to land use } \\
\text { permit process by private } \\
\text { companies }\end{array}$} & $\begin{array}{l}\text { Some community-owned oil palm plantations do not } \\
\text { have appropriate permits }\end{array}$ \\
\hline & & Problems with company boundaries \\
\hline \multirow[t]{3}{*}{ Public involvement } & \multirow[t]{3}{*}{$\begin{array}{l}\text { Lack of community } \\
\text { empowerment }\end{array}$} & $\begin{array}{l}\text { Community's right to manage forest is a lower priority } \\
\text { for government }\end{array}$ \\
\hline & & $\begin{array}{l}80 \% \text { of forest rights controlled by companies, and } \\
\text { people's rights to access forest becomes limited. This } \\
\text { makes local people become marginalized and poor. }\end{array}$ \\
\hline & & $\begin{array}{l}\text { Lack of empowerment by Forestry Agency for the local } \\
\text { communities in and around forest areas }\end{array}$ \\
\hline \multirow[t]{4}{*}{ Conflicts } & \multirow[t]{4}{*}{$\begin{array}{l}\text { Conflict between communities } \\
\text { and companies }\end{array}$} & $\begin{array}{l}\text { Conflict between community and oil and gas company } \\
\text { on land tenure }\end{array}$ \\
\hline & & $\begin{array}{l}\text { Inadequate land compensation for communities by } \\
\text { companies }\end{array}$ \\
\hline & & $\begin{array}{l}\text { Company CSR program is not utilized optimally for } \\
\text { community empowerment }\end{array}$ \\
\hline & & Overlapping mine concessions \\
\hline
\end{tabular}

Sources: interviews and discussions

\subsubsection{Musi Rawas}

Musi District is located in the western part of South Sumatra Province with an area of 635,717.15 ha. Musi Rawas is one of the more developed areas in South Sumatra Province because of its abundant natural resources, which include food production center, plantations and buffer zone of a part of Kerinci Seblat National Park that lies within the district. The district population in 2015 is 384,444 people, with a population density of 60 people per $\mathrm{km}^{2}$. The densest populated sub-district is Tugu Mulyo with a population density of 674 people per $\mathrm{km}^{2}$.

Diverse topography ranging from lowlands to highlands makes this district is suitable for plantations. Plantation is the dominant land use in this district, covering about $33.74 \%$ of the total district area or 214,482 hectares. Rubber is the growing plantation commodity in Musi Rawas. Other types of land 
cover include non-agricultural land with $28.74 \%$ or $182,697.15$ ha, rice fields with 30,366 ha or about $4.78 \%$. Meanwhile, forests cover an area of $277.274,97$ ha in which $74,18 \%$ is production forest that produce timber forest products.

Table 9. Details of land use and administration problems in Musi Rawas District based on stakeholders' perspective.

\begin{tabular}{|c|c|c|}
\hline Categories & Problems & Musi Rawas \\
\hline \multirow[t]{2}{*}{ Land administration } & \multirow[t]{2}{*}{$\begin{array}{l}\text { Unclear land administration } \\
\text { (including land certification, land } \\
\text { ownership data, etc.) }\end{array}$} & $\begin{array}{l}\text { Sustainable production forest management (PHPL) } \\
\text { certification is issued even when problems are still } \\
\text { unresolved }\end{array}$ \\
\hline & & BPN issued land certificates for land in forest areas \\
\hline \multirow[t]{6}{*}{ Illegal land use } & \multirow{6}{*}{$\begin{array}{l}\text { Illegal land use, including } \\
\text { encroachment, land conversion, } \\
\text { etc. }\end{array}$} & Open access in ex-concession areas \\
\hline & & Land occupation by transmigrants \\
\hline & & $\begin{array}{l}\text { Forest encroachment for farmlands (rice field, oil palm, } \\
\text { rubber) or settlements by communities }\end{array}$ \\
\hline & & Shifting cultivation is still common practice \\
\hline & & Villages located inside forest areas \\
\hline & & $\begin{array}{l}\text { Local governments build roads on ex-logging and pulp } \\
\text { and paper concession that do not comply with spatial } \\
\text { plan }\end{array}$ \\
\hline Conflict management & Ineffective conflict management & $\begin{array}{l}\text { There is no local government initiative to address the } \\
\text { problem of the open-access areas }\end{array}$ \\
\hline Information and data & $\begin{array}{l}\text { Information and data } \\
\text { management }\end{array}$ & $\begin{array}{l}\text { Land use and land administration database have not } \\
\text { been improved }\end{array}$ \\
\hline \multirow[t]{2}{*}{ Policy and regulation } & \multirow[t]{2}{*}{$\begin{array}{l}\text { Lack of synergy (inconsistency) } \\
\text { in regulations and policies }\end{array}$} & $\begin{array}{l}\text { Different regulations between different government } \\
\text { sectors }\end{array}$ \\
\hline & & $\begin{array}{l}\text { Inconsistencies among licensing authorities between } \\
\text { BPMPT and relevant land-based government agencies }\end{array}$ \\
\hline \multirow[t]{2}{*}{ Land Conversion } & \multirow{2}{*}{$\begin{array}{l}\text { Land conversion not in } \\
\text { accordance with its designation }\end{array}$} & Conversion from farmland to other uses \\
\hline & & $\begin{array}{l}\text { There is a tendency for rice fields to be converted into } \\
\text { rubber/oil palm plantations/fish ponds because they are } \\
\text { designated as strategic areas under District Spatial } \\
\text { Plan (RTRWK) }\end{array}$ \\
\hline \multirow[t]{3}{*}{ Coordination } & \multirow[t]{2}{*}{ Poor cross-sectoral coordination } & $\begin{array}{l}\text { Lack of coordination between local government work } \\
\text { units and other sectoral agencies, such as coordination } \\
\text { between local government with the Forestry Agency }\end{array}$ \\
\hline & & High sectoral ego \\
\hline & $\begin{array}{l}\text { Poor coordination between } \\
\text { central and local governments }\end{array}$ & Forest area use proposals lack local recommendations \\
\hline Resources & $\begin{array}{l}\text { Lack of government resources } \\
\text { (including lack of budget, human } \\
\text { resources, etc.) }\end{array}$ & $\begin{array}{l}\text { Limited human resources in monitoring permits and } \\
\text { implementation }\end{array}$ \\
\hline \multirow[t]{3}{*}{$\begin{array}{l}\text { Land use permit } \\
\text { process }\end{array}$} & \multirow[t]{3}{*}{$\begin{array}{l}\text { Problems related to land use } \\
\text { permit process by private } \\
\text { companies }\end{array}$} & $\begin{array}{l}\text { Non-procedural permits: licenses that are not in } \\
\text { accordance with the local technical considerations, } \\
\text { permit shortcut, etc. }\end{array}$ \\
\hline & & $\begin{array}{l}\text { Land authority of land permits has not been all } \\
\text { transferred to BPMPT so that some related offices still } \\
\text { use their own rules. }\end{array}$ \\
\hline & & $\begin{array}{l}\text { Companies' non-compliance with land use permits, } \\
\text { such as planting outside the permitted area }\end{array}$ \\
\hline
\end{tabular}




\begin{tabular}{|c|c|c|}
\hline & & $\begin{array}{l}\text { Some illegal activities without licenses, such as illegal } \\
\text { gold mining and quarrying }\end{array}$ \\
\hline & & $\begin{array}{l}\text { Processing land use permits in forest areas is time- } \\
\text { consuming }\end{array}$ \\
\hline \multirow[t]{3}{*}{ Maps } & \multirow{3}{*}{$\begin{array}{l}\text { Map related issues (including } \\
\text { unclear boundaries) }\end{array}$} & Maps inconsistencies \\
\hline & & $\begin{array}{l}\text { There are companies that are late to the boundary so } \\
\text { as to influence land conflicts }\end{array}$ \\
\hline & & Delay in determining land boundaries \\
\hline \multirow[t]{2}{*}{ Regulations } & \multirow{2}{*}{$\begin{array}{l}\text { Regulations are not fully } \\
\text { enforced }\end{array}$} & Problems related to transmigrant areas \\
\hline & & $\begin{array}{l}\text { SKPDs do not fully enforce all the regulation in the } \\
\text { district }\end{array}$ \\
\hline \multirow[t]{3}{*}{ Conflicts } & \multirow{3}{*}{$\begin{array}{l}\text { Conflict between communities } \\
\text { and companies }\end{array}$} & Inadequate land compensation for communities \\
\hline & & $\begin{array}{l}\text { Differences in land use allocation between } \\
\text { transmigrants and companies }\end{array}$ \\
\hline & & Overlapping land use between plantation and forestry \\
\hline \multirow[t]{3}{*}{ Overlap } & Overlapping land use & $\begin{array}{l}\text { Overlapping land use between plantation and forestry; } \\
\text { mining and industrial forest, etc. }\end{array}$ \\
\hline & \multirow[t]{2}{*}{ Overlapping land use permits } & $\begin{array}{l}\text { Overlapping land use between plantations and mines } \\
\text { due to conflicting land use permits }\end{array}$ \\
\hline & & $\begin{array}{l}\text { Overlapping land use among mining companies due to } \\
\text { differences in mineral utilization }\end{array}$ \\
\hline
\end{tabular}

Sources: interviews and discussions

\subsection{Central Java}

Central Java comprises an area of $32,544.12 \mathrm{~km}^{2}$ or approximately $25 \%$ of the total Java Island area. The province is further divided into 29 districts and 6 municipalities. The three districts selected for the study are Banyumas, Purbalingga and Banjarnegara. Central Java is one of the most important food producers for Indonesia's national food stock, therefore agriculture is one of the main issues in the region. Central Java illustrates a province dealing with challenges in land needed for agriculture and settlements, challenges in land administration systems, and pressure on remaining forest areas in the province.

At the provincial level, Central Java Province has issued Regulation No. 6 in 2010 on 2009-2029 Provincial Spatial Plan (RTRWP). Banjarnegara District issued its Regional Regulation on Banjarnegara District Spatial Plan (RTRWK) No. 11 in 2011, while Banyumas District issued its District Spatial Plan No.10 in 2011 and Purbalingga District passed its Regional Spatial Plan No. 5 in 2011. District Spatial Plan provides reference for Long Term or Medium Term District Development Plans (RPJPD and RPJMD), land use and district development, investment sites within a district, Detailed Spatial Plan (RDTR), grounds for managing land use, and as reference in the implementation of land administration. 


\subsubsection{Similar Problems across 3 Districts in Central Java}

The three selected districts in the study have nearly identical conditions as major agriculture districts. There are 4 main issues that came up in each district pertaining to information and data, coordination, spatial planning process, and implementation of regulations.

Table 10. Majority of LULA problems occurring in the 3 districts in Central Java.

\begin{tabular}{ll}
\multicolumn{1}{c}{ Categories } & \multicolumn{1}{c}{ Problems } \\
\hline Information and data & Data and information management needs improvement \\
\hline Coordination & Poor cross-sectoral coordination \\
\hline $\begin{array}{l}\text { Land use planning } \\
\text { process }\end{array}$ & $\begin{array}{l}\text { Problems in spatial plan processes, such as the long duration, high budget requirements, and } \\
\text { lack of public involvement }\end{array}$ \\
\hline Implementation & Numerous problems encountered when implementing regulations on the ground \\
\hline
\end{tabular}

Sources: interviews discussions and analysis

Spatial plan preparations must involve stakeholders. Stakeholder representation in RTRW preparation is still a problem in the districts. There are stakeholders who are dissatisfied with the results. In Banyumas for example, there is dissatisfaction on the part of housing developers whose numbers may be in the hundreds but only 2-3 representatives were involved in the process, and they are not considered to represent the interests of the group. All real interests should be represented during the regional spatial planning process although may not be addressed $100 \%$ due to budget, time and other limitations.

Spatial planning process has become one of the main problems in the three districts. Although districts already have their district spatial plans, they do not yet have Detailed Spatial Plans, even across districts in the province. Spatial planning is considered a complicated and time-consuming process. The macro-level district spatial plan is forced to act as reference for the highly technical land use of the currently non-existing detailed plan should be. Thus, the district spatial plan cannot accommodate the numerous interests in the districts.

District spatial plan is developed for a 20-year period. There is a possibility that spatial plans will become incompatible with future conditions. The importance of revising the spatial plan is to anticipate the occurrence of malpractice between the needs and capabilities of the land itself. RTRW may be reviewed every 5 years and Banyumas District is currently preparing to review its spatial plan document at the time of this study. There are varying perceptions and understanding towards Spatial Plan Regulation among the SKPD (local government work units). In Purbalingga, it was stated that the spatial plan document is sometimes out of sync with other development plan documents such as RPJMD and RPJP. This may be due to the fact that district development plan documents are issued before spatial plan documents, while spatial plan should provide the basis or reference for all development plans. 
In the three districts, there are land use practices that do not comply with the intended purpose as stated in the spatial plan. In Banyumas District, there is a settlement inside PT Perhutani, conversion of plantations into rice fields in areas that should not be cleared, buildings or land use along river banks, and land use change from productive rice fields to other purposes. In Purbalingga District, rice fields have declined by up to 500 ha. Meanwhile in Banjarnegara District, it is a common public practice to build along river banks that should instead be designated as protected areas.

\subsubsection{District-Specific Problems in Central Java}

\subsubsection{Banyumas}

Banyumas district covers 1,327.59 $\mathrm{km}^{2}$ of lowland topography. Based on the 2016 population projection, Banyumas District population is 1,650,625 people with a density of 1,243 inhabitants per $\mathrm{km}^{2}$. Banyumas District' forest is areas cover 25,643.01 hectares, comprising mostly production forest $(12,789.78 \mathrm{ha})$, followed by protected forest and limited production forest.

In the Banyumas District FGD, there is a notion that each SKPD sometimes have different perceptions about Spatial Regulations. It was noted that the community is not accustomed to applying for IMB and it seems that not many people are concerned about IMB requirements during building constructions processes. Those who do apply for IMB usually do so with underlying reasons, such as to access bank loans. The main reason for the reluctant in IMB application is the expensive permit cost.

A portion of Banyumas District is part of West Banyumas and East Banyumas FMUs of PT Perhutani Unit I that manage the forest area. With regards to spatial plan process, there is no problem on forest boundaries. PT Perhutani is managed in compliance with forest conservation plans. PT Perhutani submits periodic reports to the local government as a form of the company's cooperation, as well as involving surrounding communities in social forestry programs.

Table 11. Details of land use and administration problems in Banyumas District based on stakeholders' perspective.

\begin{tabular}{lll}
\multicolumn{1}{c}{ Categories } & \multicolumn{1}{c}{ Problems } & \multicolumn{1}{c}{ Banyumas } \\
\hline Land administration & $\begin{array}{l}\text { Unclear land administration } \\
\text { (including land certification, } \\
\text { land ownership data, etc.) }\end{array}$ & $\begin{array}{l}\text { IMB or land certificate is not an indicator for land } \\
\text { suitability whose legality is recognized by the majority } \\
\text { of the public }\end{array}$ \\
\hline Illegal land use & $\begin{array}{l}\text { Illegal land use, including } \\
\text { encroachment and land } \\
\text { conversion non-compliant } \\
\text { with spatial plan }\end{array}$ & $\begin{array}{l}\text { Settlements and unlicensed businesses are built in } \\
\text { protected areas such as riverbanks }\end{array}$ \\
\cline { 2 - 3 } & $\begin{array}{l}\text { Land conversion not in } \\
\text { accordance with land } \\
\text { designation }\end{array}$ & $\begin{array}{l}\text { Agroforestry buffer zones are transformed into } \\
\text { settlements }\end{array}$ \\
\cline { 2 - 2 } & $\begin{array}{l}\text { Conversion of farmland (agroforestry) into rice fields } \\
\text { without referring to spatial plan }\end{array}$ \\
\hline $\begin{array}{l}\text { Conversion of land not in accordance with its } \\
\text { designation is frequently linked to large companies }\end{array}$ \\
\hline
\end{tabular}




\begin{tabular}{ll} 
Information and data & $\begin{array}{l}\text { Information and data } \\
\text { management }\end{array}$ \\
\hline Coordination & $\begin{array}{l}\text { Poor cross-sector } \\
\text { coordination }\end{array}$
\end{tabular}

High rate of spatial regulation violations by communities due to lack of understanding of the regulations

\begin{tabular}{|c|c|c|}
\hline & & $\begin{array}{l}\text { Different perceptions among each SKPD on spatial } \\
\text { plan regulations }\end{array}$ \\
\hline \multirow[t]{3}{*}{ Resources } & \multirow{2}{*}{$\begin{array}{l}\text { Lack of government } \\
\text { resources (including lack of } \\
\text { budgets, human resources, } \\
\text { etc.) }\end{array}$} & Lack of human resources to monitor land use \\
\hline & & $\begin{array}{l}\text { Lack of human resources on the ground to respond to } \\
\text { spatial regulation violations, such as public order police } \\
\text { (Satpol-PP) }\end{array}$ \\
\hline & Limited land resources & $\begin{array}{l}\text { Limited land for land-based businesses or economic } \\
\text { investment }\end{array}$ \\
\hline \multirow[t]{2}{*}{$\begin{array}{l}\text { Land use permit } \\
\text { process }\end{array}$} & \multirow{2}{*}{$\begin{array}{l}\text { Problems related to land } \\
\text { use permit process by } \\
\text { private companies }\end{array}$} & $\begin{array}{l}\text { Land use practice that is not in accordance with its } \\
\text { permits }\end{array}$ \\
\hline & & $\begin{array}{l}\text { Some private companies take illegal shortcuts to } \\
\text { process business permits. The technical licensing } \\
\text { team lacks coordination with the spatial management } \\
\text { team, so fraud still occurs }\end{array}$ \\
\hline \multirow[t]{6}{*}{ Spatial plan process } & \multirow{4}{*}{$\begin{array}{l}\text { Problems on spatial plan } \\
\text { processes }\end{array}$} & Land use plan not in accordance with the land potential \\
\hline & & $\begin{array}{l}\text { Spatial plan document needs to be reviewed for its } \\
\text { feasibility with land potential }\end{array}$ \\
\hline & & $\begin{array}{l}\text { Complex, multi-interest and time consuming } \\
\text { bureaucracy involved in spatial plan processes }\end{array}$ \\
\hline & & $\begin{array}{l}\text { Contents of RTRW regulation are not in accordance } \\
\text { with the technical conditions on the ground } \\
\text { (boundaries, strategic area, land potential) }\end{array}$ \\
\hline & Lack of public involvement & Lack of public involvement in spatial planning process \\
\hline & $\begin{array}{l}\text { Problems related to detail } \\
\text { spatial plan }\end{array}$ & $\begin{array}{l}\text { Detail spatial plan is not yet ready and small-scale map } \\
\text { in regional spatial plan cannot provide a good } \\
\text { reference for technical land use on the ground }\end{array}$ \\
\hline \multirow[t]{3}{*}{ Regulations } & \multirow[t]{2}{*}{$\begin{array}{l}\text { Poor implementation of } \\
\text { regulations }\end{array}$} & $\begin{array}{l}\text { Poor government implementation of spatial regulations } \\
\text { and spatial regulation oversight }\end{array}$ \\
\hline & & Regulations on spatial violations are not fully enforced \\
\hline & $\begin{array}{l}\text { Spatial regulation is } \\
\text { considered complicated }\end{array}$ & $\begin{array}{l}\text { Spatial plan methods in Indonesia are not yet in } \\
\text { accordance with local characteristic }\end{array}$ \\
\hline Maps & $\begin{array}{l}\text { Problems related to maps, } \\
\text { including boundaries }\end{array}$ & $\begin{array}{l}\text { Unsettled boundaries between some administrative } \\
\text { areas }\end{array}$ \\
\hline Overlap & Overlapping land use & $\begin{array}{l}\text { Frequent claims of land use between investors, } \\
\text { communities and governments }\end{array}$ \\
\hline
\end{tabular}

Sources: interviews and discussions

\subsubsection{Purbalingga}

Purbalingga District has an area of 77,764,122 ha. The total population based on 2016 projection is 907,507 people with a population density of 1,167 people per $\mathrm{km}^{2}$. Agriculture is a dominant land use in the area, especially for food crops. Wetlands cover 21,075 ha. Commodities with the highest production in Purbalingga are cassava and ketala vera, while primary plantation commodities are domesticated coconut (kelapa dalam), coconut milk, and coffee. 
In Purbalingga district, land owned by PT KAI (Indonesian Railway Company) is part of a problem regarding differences in authority and regulation. There are no standard regulations governing the coordination between PT KAI and Bappeda, as is the case between PT Perhutani and local government. Then how do these two government agencies coordinate?

Another issue that may potentially surface is regarding conflicting land use with the Sustainable Food Crops Land (LP2B) program as stipulated in Law No. 41 of 2009. As mentioned by an FGD participant in Purbalingga, this program is too idealistic and difficult to implement. Program requirements that must be are too detailed and cannot be applied to current local conditions. For example, farmers whose land is included in the program will receive incentives in the form of reduced land tax. This becomes a challenge when not all famer-owned land are officially recorded. According to the FGD participant, it would have been easier if the regulation was less detailed.

Table 12. Details of land use and administration problems in Purbalingga District based on stakeholders' perspective.

\begin{tabular}{|c|c|c|}
\hline Categories & Problems & Purbalingga \\
\hline \multirow[t]{3}{*}{ Conflict } & \multirow[t]{3}{*}{ Ineffective conflict management } & $\begin{array}{l}\text { Land conflicts have often been brought to trials but } \\
\text { are still unresolved. }\end{array}$ \\
\hline & & $\begin{array}{l}\text { Land conflict between local government with PT KAI } \\
\text { is unresolved }\end{array}$ \\
\hline & & $\begin{array}{l}\text { Land conflicts resolutions are confirmed if a major } \\
\text { disaster occurs and community asks for } \\
\text { compensation }\end{array}$ \\
\hline \multirow[t]{2}{*}{ Information and data } & Information and data regulation & $\begin{array}{l}\text { There is no regulation requiring districts to socialize } \\
\text { spatial plans to villages }\end{array}$ \\
\hline & $\begin{array}{l}\text { Lack of public socialization of spatial } \\
\text { plan regulation }\end{array}$ & Most people do not understand spatial regulation \\
\hline \multirow[t]{3}{*}{ Regulations } & $\begin{array}{l}\text { Lack of synergy (inconsistency) in } \\
\text { regulations and policies }\end{array}$ & $\begin{array}{l}\text { Unclear regulation on the authorities of PT KAI and } \\
\text { local government regarding land management in PT } \\
\text { KAI in the region. There is no regulation that obliges } \\
\text { Indonesian Perhutani and Bappeda to coordinate on } \\
\text { spatial planning }\end{array}$ \\
\hline & \multirow[t]{2}{*}{ Regulations are not fully enforced } & $\begin{array}{l}\text { Land use permits are not fully enforced, especially } \\
\text { those related to private company investments }\end{array}$ \\
\hline & & $\begin{array}{l}\text { Decision makers (heads of districts) can instantly } \\
\text { change land use, although its designation is not in } \\
\text { accordance with RTRWK, if they see it as high } \\
\text { economic investment }\end{array}$ \\
\hline \multirow[t]{4}{*}{ Coordination } & \multirow[t]{2}{*}{ Poor cross-sectoral coordination } & $\begin{array}{l}\text { Overlapping authorities between government } \\
\text { agencies and companies in the districts, such as } \\
\text { between SKPDs, PT Perhutani and PT KAI }\end{array}$ \\
\hline & & Lack of coordination between land-based SKPD \\
\hline & \multirow[t]{2}{*}{$\begin{array}{l}\text { Poor coordination between central } \\
\text { and local governments }\end{array}$} & $\begin{array}{l}\text { The local government was not engaged during PT } \\
\text { KAl's land permit processes, yet local government is } \\
\text { given a mandate to monitor PT KAl's activities. The } \\
\text { same happens with permits to use the forest area } \\
\text { inside the PT Perhutani }\end{array}$ \\
\hline & & $\begin{array}{l}\text { Local government cannot take part in managing land } \\
\text { under central government authority, even though the } \\
\text { particular area is located within its boundaries }\end{array}$ \\
\hline
\end{tabular}


Sources: interviews and discussions

\subsubsection{Banjarnegara}

Banjarnegara district covers an area of 106,970,997 ha or about 3.29\% of the entire Central Java Province areas. Banjarnegara is located in a mountainous region in the middle of the western Central Java. The dominant topography in Banjarnegara is mountain with steep relief. The population of Banjarnegara in 2016 is 907,410 people with an average density of 848 people per $\mathrm{km}^{2}$. Agriculture is the dominant land use in the district. on-agricultural land cover 19,913 hectares or about $18.62 \%$ of the total district. Other types of land use include rice fields (14,269 ha) and forest areas (17,136.18 ha) that comprises 2,112.76 ha protected forest and 15,023.42 ha production forest.

Obtaining land use permit is considered to be complex and time consuming. Procedures to obtain business licenses are in place and clear but lengthy. The process involves numerous requirements such as technical permits issued by several relevant SKPDs, including environmental permits issued by Local Environmental Agency, recommendation from Spatial Plan Coordination Board (BKPRD), Nuisance Permit (HO) from PTSP, operating permits and so on.

Moreover, investors' preferred land can also sometimes cause problems. Most investors want cheap land with good accessibility and supporting infrastructures and facilities. Meanwhile, land designated as industrial zone may not be entirely desirable for investors. This can lead to zoning violations, such as industry construction in non-industrial areas. This is also supported by decision-makers who at times take investors' side rather than the spatial plan regulation. Decision makers are sometimes weak in implementing regulations if faced with greater political interest.

PT KAI still has an unresolved dispute regarding coordination with the Banjarnegara District Government. The district government was not involved at all in managing the land within its jurisdiction. PT KAI's land use at times are do not conform to district plans. The Banjarnegara District Government hopes that all land use in the district are coordinated in advance so as not to cause problems later.

In the three districts, there are land use practices that are not in accordance with its designated purpose as stated in the spatial plan document. In Banyumas District, there are cases of settlement located inside PT Perhutani’s concession, conversion of plantations into rice fields in areas that should not have been cleared, buildings or land use along river banks, and land use change from productive rice fields to other purposes. In Purbalingga District, rice fields have declined by up to 500 ha. Meanwhile in Banjarnegara District, it is a common public practice to build along river banks that should instead be designated as protected areas. 
Limited community land ownership is one of the main reasons to the frequent spatial plan regulation violations. Land owners feel like they do not have any choice. Community land use outside of cities are usually unlicensed. Meanwhile, most investors with large capital usually have legal permits. However, the problem is that their practices and implementation are not in accordance with the permits.

Local government still experience spatial plan violations by communities. The underlying reason is that many violations have been ignored for too long by the government and involve the public in large numbers. For example, construction along river banks are common and difficult to regulate because it involves many people. The lack of personnel makes this challenge even greater. Repressive action will only at trigger protest from others.

In addition, the government has not found a solution to banning rice fields conversion into settlements. Prohibiting the conversion of rice fields into the settlements or constructions along river banks can be done only by providing a solution so that the people's livelihoods are not disrupted. One solution is providing compensation or incentive to the public. However, this is a difficult solution. In addition, there is no regulation regarding spatial incentives. Possible incentives are from Land and Building Tax (PBB) incentives regulated by the local governments.

Table 13. Details of land use and administration problems in Banjarnegara District based on stakeholders' perspective.

\begin{tabular}{|c|c|c|}
\hline Categories & Problems & Banjarnegara \\
\hline Data and information & $\begin{array}{l}\text { Poor data and } \\
\text { information } \\
\text { management }\end{array}$ & Public still does not understand spatial plan regulation \\
\hline \multirow[t]{10}{*}{ Regulations } & \multirow{2}{*}{$\begin{array}{l}\text { Lack of synergy } \\
\text { (inconsistency) among } \\
\text { regulations and } \\
\text { policies }\end{array}$} & $\begin{array}{l}\text { Lack of synergy between spatial plan (RTRWK) and } \\
\text { development plan (RPJMD) }\end{array}$ \\
\hline & & RPJM was created without referencing RTRWK \\
\hline & \multirow[t]{8}{*}{$\begin{array}{l}\text { Poor regulation } \\
\text { implementation }\end{array}$} & Lax enforcement of spatial plan regulation violation \\
\hline & & Implementation of RTRWK is difficult \\
\hline & & $\begin{array}{l}\text { There is no detailed technical and operation regulation on } \\
\text { Sustainable Food Crops Land Protection (PLP2B) program }\end{array}$ \\
\hline & & $\begin{array}{l}\text { PLP2B faces the challenge of lack of incentives and } \\
\text { compensations for the farmers. }\end{array}$ \\
\hline & & Lax enforcement of spatial plan regulation violation \\
\hline & & Implementation of RTRWK is difficult \\
\hline & & $\begin{array}{l}\text { There's no detail regulation that is more technical and } \\
\text { operational about sustainable crops land }\end{array}$ \\
\hline & & $\begin{array}{l}\text { Program of protection of sustainable food crops (PLP2B) is } \\
\text { challenged by lack of incentives and compensations for the } \\
\text { farmers. }\end{array}$ \\
\hline Illegal land use & $\begin{array}{l}\text { Land conversion that } \\
\text { is not in accordance } \\
\text { with its designation }\end{array}$ & $\begin{array}{l}\text { Conversion of agricultural land into other land use in accordance } \\
\text { with spatial plan }\end{array}$ \\
\hline Coordination & $\begin{array}{l}\text { Poor cross-sectoral } \\
\text { coordination }\end{array}$ & $\begin{array}{l}\text { Spatial plan superintendent cannot work because its authority } \\
\text { overlaps with that of other agencies (SKPD, BUMN/D, big }\end{array}$ \\
\hline
\end{tabular}




\begin{tabular}{lll}
\hline & $\begin{array}{l}\text { Environmental } \\
\text { problems }\end{array}$ & Land carrying capacity decreases with increasing population \\
\hline Conflicts & $\begin{array}{l}\text { Community and } \\
\text { company conflicts }\end{array}$ & $\begin{array}{l}\text { Industrial reserve land allocated for local development is located } \\
\text { close to residential areas, therefore will require high } \\
\text { compensation fees }\end{array}$ \\
\hline $\begin{array}{l}\text { Land use planning } \\
\text { process }\end{array}$ & $\begin{array}{l}\text { Problems related to } \\
\text { detailed spatial plan }\end{array}$ & $\begin{array}{l}\text { The spatial pattern map scale is too small and provides technical } \\
\text { constraints for cultivation area designation }\end{array}$ \\
\cline { 2 - 3 } & $\begin{array}{l}\text { RDTR is not yet established. It is difficult to implement program } \\
\text { in the field with current map }\end{array}$ \\
\cline { 2 - 3 } & $\begin{array}{l}\text { The spatial plan map only shows presence of land reserves but } \\
\text { cannot specify the location }\end{array}$ \\
\cline { 2 - 3 } Complex spatial plan & $\begin{array}{l}\text { Complex and time-consuming spatial planning provides } \\
\text { constraint for investment. }\end{array}$ \\
\cline { 2 - 2 } & $\begin{array}{l}\text { Inputs and suggestions made during RTRW and RPJM } \\
\text { socialization were not addressed }\end{array}$ \\
\cline { 2 - 2 } & $\begin{array}{l}\text { Designation of industrial estate is still confusing and without legal } \\
\text { basis }\end{array}$ \\
\hline
\end{tabular}

Sources: interviews and discussions

\subsection{East Kalimantan}

East Kalimantan Province covers 127,267.52 $\mathrm{km}^{2}$ land area and 25,656 $\mathrm{km}^{2}$ territorial waters. With its development and expansion, East Kalimantan is divided into 7 districts and 3 municipalities. The three districts selected for the study - Paser, Berau, and East Kutai - are also some of the sites of GELAMAI (Green Economy - Locally Appropriate Mitigation Action in Indonesia) project. East Kalimantan is one of the main gates in eastern Indonesia. The region, known for its timber and mining, is home to hundreds of rivers flowing to nearly every district and municipality which are used as primary transportation next to land transportation, and the largest river is Mahakam River (Statistic Centre Agency 2015).

East Kalimantan illustrates a province in Indonesia facing the challenges of natural resources management, land administration policy to secure spatial and land rights in land use, as well as improve the province's future investment and development.

At the provincial level, East Kalimantan government has issued regulation on 2016-2036 East Kalimantan Provincial Spatial Plan No. 1 in 2016. Meanwhile at the district level, Paser issued its District Spatial Plan No. 9 in 2015, East Kutai issued its District Spatial Plan of No. 1 in 2016, and meanwhile Berau has not issued its District Spatial Plan. At the time of the report, Berau District is still drafting its district spatial plan regulation. 


\subsubsection{Similar Problems across 3 Districts in East Kalimantan}

In general, the problems in East Kalimantan are quite varied compared to other provinces. In the three districts surveyed, we found many similar problems related to land administration, illegal land use, lack of information and data management, regulation, land conflicts, stakeholder coordination, community engagement and overlapping land use. Table 14 presents detailed account of the similar problems occurring across the 3 districts in East Kalimantan Province.

The problems that arise in three districts in East Kalimantan are similar due to the districts' similar natural, socio-economic and regional conditions. All three study sites in East Kalimantan is plantation development, especially oil palm, and mining. The need for land is similar thus the problems are similar.

Table 14. Majority of LULA problems occurring in the 3 districts in East Kalimantan.

\begin{tabular}{ll}
\multicolumn{1}{c}{ Categories } & \multicolumn{1}{c}{ Problems } \\
\hline Illegal land use & Unclear land administration (including land certification, land ownership data, etc.) \\
\hline \multirow{2}{*}{ Information and data } & Illegal land use, including encroachment and land occupation \\
\cline { 2 - 2 } & Land conversion not in accordance with land designation \\
\hline Regulation & Information and data management still need improvement \\
\cline { 2 - 2 } & Lack of socialization of government programs and regulations \\
\hline Land conflict & Lack of synergy (inconsistency) of regulations and policies \\
\cline { 2 - 2 } Coordination & Poor regulation implementation \\
\hline Public involvement & Land conflicts \\
\hline Overlapping land use & Lack of coordination between central and local governments \\
\hline & Lack of public involvement \\
\hline
\end{tabular}

Sources: interviews discussions and analysis

\subsubsection{District-Specific Problems in East Kalimantan}

Nevertheless, each district has faces its own set of different and specific problems in their respective regions.

\subsubsection{Paser District}

Paser District is located in the southern part of East Kalimantan Province with an area of 11,603.94 $\mathrm{km}^{2}$, consisting of $10,851.18 \mathrm{~km}^{2}$ land and $752.76 \mathrm{~km}^{2}$ territorial waters. The district population in 2016 is 268,261 people with 25.91\% of the population occupying the district capital in Tanah Grogot Sub-District. The primary land use in Paser District is agriculture, including plantations with an area of 1,102,107 hectares and rice fields covering 11.306 ha. The major plantation commodity is oil palm which grows annually. Palm oil production in 2016 was 2,127,990.34 tons, which was a 55.96\% increase compared to the previous year. The total oil palm plantation area in 2016 is 180,328.72 ha in which 79,213 ha are smallholdings and the rest are company-managed plantations. 
In 2016, 69\% of 1,824 land applications in the district were completed (BPS, 2017), including applications for measurement, ground maps, Land Rights Certificates, Land Transfer Certificates, Certificates of Loans and Certificates of credit guarantee and mortgage guarantee.

In Paser District, discussion participants shared that it is difficult for SKPDs to coordinate on spatial planning. BKPRD acts as coordination forum in the district, chaired by District Secretary and representatives from agencies in Paser, but still cannot function optimally, and even tends to be passive. In the past there was the SIG Forum which could act as coordination forum on spatial information in Paser had it not been dissolved. According to FGD participants, the forum was quite helpful to coordinate agencies in the district. BKPRD was expected to be a coordination forum like this despite the fact cannot be so.

A number of villages are located within Forest Management Unit areas FMU in Paser, Berau and East Kutai, and to this day these villages have not been released or enclaved. It is said that this process is currently ongoing. Whereas in urban areas, green open spaces are prone to conflicts of interest between the need for public space and business interests. The local government is expected to be stricter in regulating this issue.

Table 15. Details of land use and administration problems in Paser District based on stakeholders' perspective.

\begin{tabular}{|c|c|c|}
\hline Categories & Problems & Detail Problems \\
\hline Land administration & $\begin{array}{l}\text { Unclear land administration } \\
\text { (including land certification, land } \\
\text { ownership data, etc.) }\end{array}$ & Repeated land sale, in which some plots are sold twice \\
\hline $\begin{array}{l}\text { Land use permit } \\
\text { process }\end{array}$ & $\begin{array}{l}\text { Complex and time-consuming } \\
\text { land use permit process }\end{array}$ & $\begin{array}{l}\text { Permit application procedure is considered to be time } \\
\text { consuming, complicated and expensive }\end{array}$ \\
\hline \multirow[t]{9}{*}{ Illegal land use } & \multirow{9}{*}{$\begin{array}{l}\text { Illegal land use, including } \\
\text { encroachment, land conversion, } \\
\text { etc. }\end{array}$} & The forest protection block is utilized by the community \\
\hline & & Communities often occupy open access land \\
\hline & & $\begin{array}{l}\text { Forest areas encroached by surrounding communities } \\
\text { for settlements or farmlands, oil palm plantation in the } \\
\text { forest area. }\end{array}$ \\
\hline & & Forest land swaps among communities \\
\hline & & Community-owned oil palm plantations in the area \\
\hline & & Sand mining in the river \\
\hline & & $\begin{array}{l}\text { Utilization of wetlands for farmlands is against } \\
\text { regulations }\end{array}$ \\
\hline & & $\begin{array}{l}\text { Some companies violate Cultivation Rights (HGU) } \\
\text { boundaries }\end{array}$ \\
\hline & & Land conversion of rice fields into oil palm plantations \\
\hline \multirow[t]{4}{*}{ Conflict management } & \multirow[t]{4}{*}{ Ineffective conflict management } & Complicated conflict resolution \\
\hline & & Lack of evaluation of conflict management \\
\hline & & $\begin{array}{l}\text { Forest partnership with communities is still considered } \\
\text { complicated }\end{array}$ \\
\hline & & $\begin{array}{l}\text { Conflict mediation between communities and forest area } \\
\text { manager (PT Inhutani) is difficult }\end{array}$ \\
\hline Information and data & Information and data & Lack of public information disclosure \\
\hline
\end{tabular}


management

Information sources are sometimes inaccurate

Incomplete database in government agencies.

Lack of socialization of public

information

Communities lack knowledge about land use permits and procedures

Lack transparency from

SKPD lacks transparency to the data they owned.

government agencies

Inadequate socialization on spatial regulation to communities. Lack of socialization to communities on forest utilization

Regulation Lack of synergy (inconsistency) of regulations and policies

Forestry regulation is not implemented in forest areas, such as the case of PT IDEKO

Different regulations among government agencies, for example different regulations between plantation and spatial plan agencies regarding land use permits, regulations between mining and farming.

Mining law is considered stronger than other laws.

Long-term forest management plan (RPHJP) has not been accommodated during development plan deliberation process. Lack of synergy between forestry and spatial plans

Continuity Program sustainability is not guaranteed

Replacements or transfers of SKPD staff in charge of spatial matters create challenges in coordination

Partnership between FMU and communities often change with leadership changes

\begin{tabular}{|c|c|c|}
\hline \multirow[t]{2}{*}{ Land conflict } & \multirow{2}{*}{$\begin{array}{l}\text { Conflict between local } \\
\text { communities and companies }\end{array}$} & Conflict between Inhutani and local communities \\
\hline & & $\begin{array}{l}\text { There is social envy between companies and } \\
\text { communities }\end{array}$ \\
\hline \multirow[t]{3}{*}{ Coordination } & \multirow{2}{*}{$\begin{array}{l}\text { Lack of cross-sectoral } \\
\text { government agencies } \\
\text { coordination }\end{array}$} & $\begin{array}{l}\text { Cross-sectoral ego between government agencies } \\
\text { (SKPD) makes coordination difficult }\end{array}$ \\
\hline & & $\begin{array}{l}\text { BKPRD is not functioning properly, sometimes conflicts } \\
\text { occur with SKPD }\end{array}$ \\
\hline & $\begin{array}{l}\text { Central and local government } \\
\text { coordination }\end{array}$ & Poor control by district heads \\
\hline \multirow[t]{6}{*}{ Resources } & \multirow{5}{*}{$\begin{array}{l}\text { Lack of government resources } \\
\text { (including lack of budgets, } \\
\text { human resources, etc.) }\end{array}$} & $\begin{array}{l}\text { Lack of HR working on spatial plan. Poor SKPD } \\
\text { performance }\end{array}$ \\
\hline & & $\begin{array}{l}\text { Lack of budget allocated for spatial plan and regulation } \\
\text { socialization, monitoring land use, and field survey }\end{array}$ \\
\hline & & Lack of FMU personnel \\
\hline & & $\begin{array}{l}\text { BPMPT is not working optimally. Some permits have not } \\
\text { been transferred to BPMPT }\end{array}$ \\
\hline & & Poor budget allocation for communities \\
\hline & Unclear agency mandate & FMU's main task and function re still considered unclear \\
\hline \multirow{4}{*}{$\begin{array}{l}\text { Land use permit } \\
\text { process }\end{array}$} & \multirow{3}{*}{$\begin{array}{l}\text { Problems related to land use } \\
\text { permit process by private } \\
\text { companies }\end{array}$} & Permit take-over among companies \\
\hline & & Incorrect license procedure \\
\hline & & $\begin{array}{l}\text { Companies committing tort, such as failing to operate } \\
\text { after obtaining land use license }\end{array}$ \\
\hline & $\begin{array}{l}\text { Poor complaints mechanism for } \\
\text { communities }\end{array}$ & $\begin{array}{l}\text { Unclear community complaints mechanism and most } \\
\text { complaints are ignored by authorities }\end{array}$ \\
\hline \multirow[t]{2}{*}{ Tax } & \multirow[t]{2}{*}{ Poor tax management } & $\begin{array}{l}\text { Natural resources tax overlap between provincial and } \\
\text { district authorities, e.g. water tax }\end{array}$ \\
\hline & & Coordination between government levels about tax \\
\hline
\end{tabular}




\begin{tabular}{|c|c|c|}
\hline & & management is still a challenge \\
\hline & & Not all land users pay land and building taxes \\
\hline Public involvement & Lack of public involvement & $\begin{array}{l}\text { Some of government programs do not involve the } \\
\text { general public }\end{array}$ \\
\hline & $\begin{array}{l}\text { Lack of community } \\
\text { empowerment }\end{array}$ & $\begin{array}{l}\text { Low understanding of spatial information, such as } \\
\text { understanding maps. }\end{array}$ \\
\hline & & $\begin{array}{l}\text { Lack of community empowerment by government, } \\
\text { especially local communities in and around forest areas }\end{array}$ \\
\hline Regulations & Poor regulation implementation & $\begin{array}{l}\text { Regulation implementation is a challenge due to the } \\
\text { numerous regulations in place }\end{array}$ \\
\hline & & $\begin{array}{l}\text { Government is lax on spatial violations, and public often } \\
\text { ignore spatial law violations }\end{array}$ \\
\hline & Lack of monitoring & Poor company monitoring \\
\hline & Lack of land use control & Poor control of land use \\
\hline $\begin{array}{l}\text { Stakeholders' } \\
\text { perception }\end{array}$ & $\begin{array}{l}\text { Different perceptions and } \\
\text { understanding about spatial plan }\end{array}$ & $\begin{array}{l}\text { Different understanding about regulations between } \\
\text { stakeholders }\end{array}$ \\
\hline & stakeholders & $\begin{array}{l}\text { There is circulating perception that if permit is submitted } \\
\text { to BPMPT then SKPD has no authority }\end{array}$ \\
\hline & & $\begin{array}{l}\text { Spatial plan regulation often perceived as investment } \\
\text { obstacles }\end{array}$ \\
\hline Spatial planning & $\begin{array}{l}\text { Problems related to spatial plan } \\
\text { processes }\end{array}$ & Wetland use plan is noncompliant with regulations \\
\hline Maps & Problems related to maps, & Different maps used among SKPDs \\
\hline & & Unfinished forest gazettement \\
\hline & & Some forest area boundaries have not been settled \\
\hline Overlapping land use & Overlapping land use & $\begin{array}{l}\text { Conflicts of interest between land use: plantation vs } \\
\text { mining, plantation vs forest area }\end{array}$ \\
\hline & & $\begin{array}{l}\text { Local communities use land inside company } \\
\text { concessions }\end{array}$ \\
\hline & Overlapping land use permits & $\begin{array}{l}\text { Overlapping permits between mining and plantation } \\
\text { companies }\end{array}$ \\
\hline & & $\begin{array}{l}\text { Local government-issued Location Permits overlap with } \\
\text { spatial plan }\end{array}$ \\
\hline
\end{tabular}

Sources: interviews and discussions

\subsubsection{Berau District}

Berau District covers 34,127.17 km². The population in 2016 is 214.828 people, with a population density of 6.3 people per $\mathrm{km}^{2}$. The main plantation commodity in Berau is oil palm with plantations, which in 2016 reached 121,415.64 ha or about 90\% of the total plantation area in the district. Berau District's forest area covers 1,604,256.2 ha and is dominated by limited production forest with $668,098.8$ ha, production forest 533,495.1 ha, protection forest 360,765.9 ha, and the remaining area are convertible production forest and education forest (BPS-Berau 2017). 
Table 16. Details of land use and administration problems in Berau District based on stakeholders’ perspective.

\begin{tabular}{|c|c|c|}
\hline Categories & Problems & Berau \\
\hline Land administration & $\begin{array}{l}\text { Unclear land administration } \\
\text { (including land certification, } \\
\text { land ownership data, etc.) }\end{array}$ & Unclear claims from communities practicing shifting cultivation \\
\hline \multirow[t]{2}{*}{ Illegal land use } & \multirow[t]{2}{*}{ Illegal land use } & Violation of HGU boundaries \\
\hline & & Conversion of karst protected areas into company concessions \\
\hline $\begin{array}{l}\text { Conflict } \\
\text { management }\end{array}$ & $\begin{array}{l}\text { Ineffective conflict } \\
\text { management }\end{array}$ & $\begin{array}{l}\text { Land allocation information is not clearly shared with } \\
\text { communities }\end{array}$ \\
\hline \multirow{7}{*}{$\begin{array}{l}\text { Information and } \\
\text { data management }\end{array}$} & \multirow{6}{*}{$\begin{array}{l}\text { Information and data } \\
\text { management }\end{array}$} & Information HGU is still not disclosed \\
\hline & & The information on website is poorly managed \\
\hline & & Database differs between companies \\
\hline & & $\begin{array}{l}\text { Community access to information is lacking/little spatial } \\
\text { interest from communities }\end{array}$ \\
\hline & & Lack of updated information on website \\
\hline & & Data distributed in certain SKPDs only \\
\hline & Lack of socialization & Lack of FPIC implementation by land-based companies \\
\hline \multirow[t]{3}{*}{ Regulations } & \multirow{2}{*}{$\begin{array}{l}\text { Lack of synergy } \\
\text { (inconsistency) of regulations } \\
\text { and policies }\end{array}$} & $\begin{array}{l}\text { District spatial plan (RTRWK) is different from province spatial } \\
\text { plan (RTRWP) }\end{array}$ \\
\hline & & Different permit guidelines (SK 718 etc.) \\
\hline & $\begin{array}{l}\text { Program sustainability is not } \\
\text { guaranteed }\end{array}$ & $\begin{array}{l}\text { Changes in government heads influence policy, not program } \\
\text { sustainability }\end{array}$ \\
\hline \multirow[t]{3}{*}{ Land conflict } & \multirow[t]{3}{*}{ Land conflict } & Conflicts between communities and companies in forest areas \\
\hline & & Forest area enclave has not been completed \\
\hline & & Horizontal conflict among communities in concession areas \\
\hline Coordination & $\begin{array}{l}\text { Poor coordination between } \\
\text { central and local governments }\end{array}$ & $\begin{array}{l}\text { Investments cannot be directed correctly from national to sub- } \\
\text { national level, there is no definite target }\end{array}$ \\
\hline Resources & $\begin{array}{l}\text { Lack of government resources } \\
\text { (including lack of budget, } \\
\text { human resources, etc.) }\end{array}$ & Limited budget for spatial plan process \\
\hline \multirow{4}{*}{$\begin{array}{l}\text { Land use permit } \\
\text { process }\end{array}$} & \multirow{3}{*}{$\begin{array}{l}\text { Problems related to land use } \\
\text { permit process by private } \\
\text { companies }\end{array}$} & Non-procedural licensing process \\
\hline & & $\begin{array}{l}\text { Abandoned/non-active logging concessions, land use license } \\
\text { misuse }\end{array}$ \\
\hline & & Land is cleared even before permit is issued \\
\hline & Money & Weak monitoring and evaluation \\
\hline Public involvement & Lack of public involvement & $\begin{array}{l}\text { Community engagement in RDTR is unclear (noncompliant } \\
\text { with existing regulations) }\end{array}$ \\
\hline Regulation & $\begin{array}{l}\text { Poor regulation } \\
\text { implementation }\end{array}$ & $\begin{array}{l}\text { License permit to some concessions do not comply with } \\
\text { designated land use }\end{array}$ \\
\hline \multirow{2}{*}{$\begin{array}{l}\text { Spatial planning } \\
\text { process }\end{array}$} & \multirow{2}{*}{$\begin{array}{l}\text { Problems related to detailed } \\
\text { spatial plan (RDTR) }\end{array}$} & RDTR is late, unfinished \\
\hline & & RDTR quality is unsatisfactory \\
\hline \multirow[t]{3}{*}{$\begin{array}{l}\text { Overlapping land } \\
\text { use }\end{array}$} & \multirow[t]{3}{*}{$\begin{array}{l}\text { Overlapping land use and land } \\
\text { use permits }\end{array}$} & $\begin{array}{l}\text { Land use is noncompliant with designation use (plantations in } \\
\text { the protected areas) }\end{array}$ \\
\hline & & Overlapping plantations and mines \\
\hline & & Overlapping companies within forest areas (FMU) \\
\hline
\end{tabular}

Sources: interviews and discussions 


\subsubsection{East Kutai}

East Kutai District is an expansion of Kutai Kertanegara District. East Kutai area covers 35,747 km² or about $17 \%$ of the total province area of. The population in 2016 is 333,591 people with a population density of 9 people per km2 (BPS-Kutai Timur 2017).

The primary plantation commodity is palm oil which reached 5,082,353,78 tons in 2016 and covers an area of 450,635.31 ha. Other land uses include agriculture, fisheries, mining, and settlements. The largest mining concession in East Kutai is a coal mine operated by PT. Kaltim Prima Coal with a management area of 90,938 hectares and production capacity of 50 million tons per year.

Table 17. Details of land use and administration problems in East Kutai District based on stakeholders' perspective.

\begin{tabular}{|c|c|c|}
\hline Categories & Problems & East Kutai \\
\hline \multirow[t]{5}{*}{ Land administration } & \multirow{5}{*}{$\begin{array}{l}\text { Unclear land administration } \\
\text { (including land certification, } \\
\text { land ownership data, etc.) }\end{array}$} & Not all land is registered in BPN \\
\hline & & $\begin{array}{l}\text { Overlapping land certificates due to unclear } \\
\text { administration and archiving from village offices }\end{array}$ \\
\hline & & Unclear transmigration land registration \\
\hline & & $\begin{array}{l}\text { Land registration problems for communities living inside } \\
\text { concession areas }\end{array}$ \\
\hline & & Overlapping and unclear land ownership in communities \\
\hline \multirow[t]{4}{*}{ Illegal land use } & \multirow[t]{4}{*}{ Illegal land use } & $\begin{array}{l}\text { Encroachment in forest areas, such as Kutai National } \\
\text { Park for settlements or farmlands }\end{array}$ \\
\hline & & Land occupation by communities in forest areas \\
\hline & & $\begin{array}{l}\text { Idle transmigration land occupied by surrounding } \\
\text { communities }\end{array}$ \\
\hline & & $\begin{array}{l}\text { Land use unsuitable with land designation, such as } \\
\text { building along river banks. }\end{array}$ \\
\hline \multirow{7}{*}{$\begin{array}{l}\text { Information and data } \\
\text { disclosure }\end{array}$} & \multirow{4}{*}{$\begin{array}{l}\text { Poor information and data } \\
\text { management }\end{array}$} & Limited improvement of information facilities \\
\hline & & $\begin{array}{l}\text { Lack of facilities to support information transparency } \\
\text { (website development) }\end{array}$ \\
\hline & & Poor information management \\
\hline & & $\begin{array}{l}\text { Lack of information coordination between companies and } \\
\text { local government }\end{array}$ \\
\hline & \multirow[t]{3}{*}{$\begin{array}{l}\text { Lack of public information } \\
\text { socialization/dissemination }\end{array}$} & $\begin{array}{l}\text { The public does not fully understand spatial plan and } \\
\text { regulations }\end{array}$ \\
\hline & & $\begin{array}{l}\text { Information on a number of regulations is poorly } \\
\text { disseminated among cross-sectoral government } \\
\text { agencies. Bappeda has not submitted RTRWK to BPN }\end{array}$ \\
\hline & & Poor information dissemination on RTRWK in villages \\
\hline \multirow[t]{2}{*}{ Policy and regulation } & $\begin{array}{l}\text { Lack of synergy (inconsistency) } \\
\text { of regulations and policies }\end{array}$ & RTRWK lacks synchronicity with forestry policies \\
\hline & $\begin{array}{l}\text { Poor implementation of } \\
\text { regulation }\end{array}$ & Spatial plan does not conform with current conditions \\
\hline
\end{tabular}




\section{Categories}

\begin{tabular}{ll} 
Land conflict & Land conflict \\
& \\
\hline Coordination & $\begin{array}{l}\text { Poor cross-sectoral } \\
\text { coordination }\end{array}$
\end{tabular}

Poor coordination among central and local government agencies

\section{East Kutai}

Conflicts between communities and companies: conflict between PT AE and farmer groups; between local communities and oil palm companies; PT Indominco and community (farmers group); between plantation and community

Lack of coordination among cross-sectoral government agencies

Lack of central government's awareness of conditions on the ground

Lack of coordination between local and central governments

Difficult for districts to monitor permits in their areas that are not in their jurisdiction

\begin{tabular}{|c|c|c|}
\hline \multirow[t]{2}{*}{ Tax management } & \multirow[t]{2}{*}{ Tax management } & $\begin{array}{l}\text { Issues related to levies and local taxes for national } \\
\text { companies }\end{array}$ \\
\hline & & $\begin{array}{l}\text { The difficulties of land and building tax (PBB) due to lack } \\
\text { of administration }\end{array}$ \\
\hline Public involvement & Lack of public involvement & $\begin{array}{l}\text { Lack of clarity in public involvement, limited to sub- } \\
\text { districts }\end{array}$ \\
\hline $\begin{array}{l}\text { Stakeholders' } \\
\text { perceptions }\end{array}$ & $\begin{array}{l}\text { Different perceptions and } \\
\text { understanding }\end{array}$ & $\begin{array}{l}\text { There is circulating perception that BPMPT will reduce } \\
\text { SKPD's technical authority }\end{array}$ \\
\hline \multirow[t]{3}{*}{ Land use planning } & \multirow[t]{3}{*}{ Problems related to spatial plan } & RTRW is later than scheduled \\
\hline & & $\begin{array}{l}\text { Existing conditions already complicated enough for } \\
\text { RTRWK compilation (no unused land) }\end{array}$ \\
\hline & & Inefficient and lengthy RTRWK drafting process \\
\hline \multirow[t]{4}{*}{ Maps } & \multirow{4}{*}{$\begin{array}{l}\text { Map related issues (including } \\
\text { unclear boundaries) }\end{array}$} & No map with 1: 5000 scale for RDTR yet \\
\hline & & Problems of different map boundaries \\
\hline & & $\begin{array}{l}\text { Unclear boundaries on the ground for forestry and non- } \\
\text { forestry cultivation areas (KBK and KBNK) }\end{array}$ \\
\hline & & $\begin{array}{l}\text { Unclear boundaries for forestry and non-forestry } \\
\text { cultivation areas (KBK and KBNK) }\end{array}$ \\
\hline \multirow[t]{5}{*}{ Overlapping land use } & \multirow[t]{3}{*}{ Overlapping land use } & Overlapping location permit in with forest areas \\
\hline & & $\begin{array}{l}\text { Overlapping plantation and mining concessions (can be } \\
\text { resolved through business-to-business mediation }\end{array}$ \\
\hline & & Overlapping land use between communities \\
\hline & \multirow[t]{2}{*}{ Overlapping permits } & Overlapping location permits \\
\hline & & Overlap mining permits with community land \\
\hline
\end{tabular}

Sources: interviews and discussions 


\section{Discussions and Conclusion}

In the study sites in four provinces, there are number of similarities and differences among the dominant problems faced in each district. Table 18 below presents the similarities and differences based on problem categories. The table is based on the same problem tables for all districts sampled in each province. The shaded (gray) cells indicate that the problem exists in the province.

Table 18. Problem Exists in The Each Region.

\begin{tabular}{|c|c|c|c|c|}
\hline \multirow{2}{*}{ Categories } & \multicolumn{4}{|c|}{ Provinces } \\
\hline & Papua & South Sumatra & Central Java & East Kutai \\
\hline \multicolumn{5}{|l|}{ Indigenous peoples } \\
\hline \multicolumn{5}{|l|}{ Land administration } \\
\hline \multicolumn{5}{|l|}{ Information and data } \\
\hline \multicolumn{5}{|l|}{ Land use permits } \\
\hline \multicolumn{5}{|l|}{$\begin{array}{l}\text { Land conversion and illegal } \\
\text { land use }\end{array}$} \\
\hline \multicolumn{5}{|l|}{ Coordination } \\
\hline \multicolumn{5}{|l|}{ Maps } \\
\hline \multicolumn{5}{|l|}{$\begin{array}{l}\text { Regulation and its } \\
\text { implementation }\end{array}$} \\
\hline \multicolumn{5}{|l|}{ Land use planning process } \\
\hline \multicolumn{5}{|l|}{ Land conflict } \\
\hline Overlapping land use & & & & \\
\hline
\end{tabular}

Differences among the problems that occur depend on stakeholders' perspectives in each province and district, which are also influenced by the area's environmental, social and economic conditions.

- The problems that occur in almost every province (appearing at least in 3 provinces) are those related to information and data management, coordination, spatial plan processes, and regulations and their implementation. These are also the most likely problems to also occur in other provinces.

- Issues involving indigenous peoples were observed in Papua Province, where there is strong customary practices and indigenous peoples' existence in the province. 


\section{Reference}

Anonymous. Indonesian Act number 26 year 2007 regarding Spatial Planning.

BPS-Statistics of Papua. 2017. Papua Province in Figure. Publication Number; 94560.1701.

BPS-Statistics of Jayapura Regency. 2016. Jayapura Regency in Figures. Publication Number: 9403.1601.

BPS-Statistics of Merauke Regency. 2017. Merauke Regency in Figures. Publication Number: 94010.1707.

BPS-Statistics of Jayawijaya Regency. 2017. Jayawijaya Regency in Figures. Publication Number: 9402.1601.

BPS-Statistics of Musirawas Regency. 2017. Musirawas Regency in Figures. Publication Number: 16056.1602.

BPS-Statistics of Banyuasin Regency. 2017. Banyuasin Regency in Figures. Publication Number: 16076.1702.

BPS-Statistics of Musi Banyuasin Regency. 2017. Musi Banyuasin Regency in Figures. Publication Number: 16060.1702.

BPS-Statistics of Central Java Province. 2017. Central Java province in Figures. Publication Number: 33560.1701.

BPS-Statistics of Banjar Negara Regency. 2017. Banjar Negara Regency in Figures. Publication Number: 33040.1702.

BPS-Statistics of Purbalingga Regency. 2017. Purbalingga Regency in Figures. Publication Number: 33030.17.02.

BPS-Statistics of Banyumas Regency. 2017. Banyumas Regency in Figures. Publication Number: 33020.1702.

BPS-Statistics of East Kalimantan. 2017. East Kalimantan Province in Figure. Publication Number; 64560.1706.

BPS-Statistics of Beurau Regency. 2017. Beurau Regency in Figures. Publication Number: 64050.1703.

BPS-Statistics of Paser Regency. 2017. Paser Regency in Figures. Publication Number: 64.016.17.03.

BPS-Statistics of Kutai Timur Regency. 2017. Kutai Timur Regency in Figures. Publication Number: 64040.1703.

Deininger K, Selod H and Burns A. 2012. The Land Governance Assessment Framework; Identifying and Monitoring Good Practice in the Land Sector. Washington DC, United States: World Bank.

Feder G and Feeny D. Goteborgs Universitet on March 30, 2012. Land Tenure and Property Rights: Theory and Implications for Development Policy. The world bank economic review, vol. 5, no. 1: 13s-153.

Lambert VA and Lambert CE. 2012. Qualitative Descriptive Research: An Acceptable Design. Pacific Rim International Journal of Nursing Research. October - December 2012.

Matternicht G. 2017. Land Use Planning. Global Land Outlook working paper.

Mitchell D et all. 2004. Assessing the Role of Land Use Planning in Natural Resource Management. FIG Working Week 2004 Athens, Greece, May 22-27, 2004.

Onyango V and Gazzola P. 2011. Regional spatial planning as a tool for addressing land injustices and mitigating land clashes: the case of Kenya. International Development Planning Review33(2): 147-167.

Ross BH and Levine MA. 2014. Urban politics: Power in Metropolitan America $7^{\text {th }}$ Edition. Study guide by Cram 101 text book review. Just the fact 101.

Young A. 1993. Guidelines for Land Use Planning. Food and Agriculture Organization of the United Nations, Rome, Italy. 


\section{WORKING PAPERS WITH DOIs}

2005

1. Agroforestry in the drylands of eastern Africa: a call to action

2. Biodiversity conservation through agroforestry: managing tree species diversity within a network of community-based, nongovernmental, governmental and research organizations in western Kenya.

3. Invasion of prosopis juliflora and local livelihoods: Case study from the Lake Baringo area of Kenya

4. Leadership for change in farmers organizations: Training report: Ridar Hotel, Kampala, 29th March to 2nd April 2005.

5. Domestication des espèces agroforestières au Sahel : situation actuelle et perspectives

6. Relevé des données de biodiversité ligneuse: Manuel du projet biodiversité des parcs agroforestiers au Sahel

7. Improved land management in the Lake Victoria Basin: TransVic Project's draft report.

8. Livelihood capital, strategies and outcomes in the Taita hills of Kenya

9. Les espèces ligneuses et leurs usages: Les préférences des paysans dans le Cercle de Ségou, au Mali

10. La biodiversité des espèces ligneuses: Diversité arborée et unités de gestion du terroir dans le Cercle de Ségou, au Mali

2006

11. Bird diversity and land use on the slopes of Mt. Kilimanjaro and the adjacent plains, Tanzania

12. Water, women and local social organization in the Western Kenya Highlands

13. Highlights of ongoing research of the World Agroforestry Centre in Indonesia

14. Prospects of adoption of tree-based systems in a rural landscape and its likely impacts on carbon stocks and farmers' welfare: The FALLOW Model Application in Muara Sungkai, Lampung, Sumatra, in a 'Clean Development Mechanism' context

15. Equipping integrated natural resource managers for healthy Agroforestry landscapes.

17. Agro-biodiversity and CGIAR tree and forest science: approaches and examples from Sumatra.

18. Improving land management in eastern and southern Africa: A review of policies.

19. Farm and household economic study of Kecamatan Nanggung, Kabupaten Bogor, Indonesia: A socio-economic base line study of Agroforestry innovations and livelihood enhancement.

20. Lessons from eastern Africa's unsustainable charcoal business.

21. Evolution of RELMA's approaches to land management: Lessons from two decades of research and development in eastern and southern Africa

22. Participatory watershed management: Lessons from RELMA's work with farmers in eastern Africa.

23. Strengthening farmers' organizations: The experience of RELMA and ULAMP.

24. Promoting rainwater harvesting in eastern and southern Africa.

25. The role of livestock in integrated land management.

26. Status of carbon sequestration projects in Africa: Potential benefits and challenges to scaling up. 
27. Social and Environmental Trade-Offs in Tree Species Selection: A Methodology for Identifying Niche Incompatibilities in Agroforestry [Appears as AHI Working Paper no. 9]

28. Managing tradeoffs in agroforestry: From conflict to collaboration in natural resource management. [Appears as AHI Working Paper no. 10]

29. Essai d'analyse de la prise en compte des systemes agroforestiers pa les legislations forestieres au Sahel: Cas du Burkina Faso, du Mali, du Niger et du Senegal.

30. Etat de la recherche agroforestière au Rwanda etude bibliographique, période 1987-2003

2007

31. Science and technological innovations for improving soil fertility and management in Africa: A report for NEPAD's Science and Technology Forum.

32. Compensation and rewards for environmental services.

33. Latin American regional workshop report compensation.

34. Asia regional workshop on compensation ecosystem services.

35. Report of African regional workshop on compensation ecosystem services.

36. Exploring the inter-linkages among and between compensation and rewards for ecosystem services CRES and human well-being

37. Criteria and indicators for environmental service compensation and reward mechanisms: realistic, voluntary, conditional and pro-poor

38. The conditions for effective mechanisms of compensation and rewards for environmental services.

39. Organization and governance for fostering Pro-Poor Compensation for Environmental Services.

40. How important are different types of compensation and reward mechanisms shaping poverty and ecosystem services across Africa, Asia \& Latin America over the Next two decades?

41. Risk mitigation in contract farming: The case of poultry, cotton, woodfuel and cereals in East Africa.

42. The RELMA savings and credit experiences: Sowing the seed of sustainability

43. Yatich J., Policy and institutional context for NRM in Kenya: Challenges and opportunities for Landcare.

44. Nina-Nina Adoung Nasional di So! Field test of rapid land tenure assessment (RATA) in the Batang Toru Watershed, North Sumatera.

45. Is Hutan Tanaman Rakyat a new paradigm in community based tree planting in Indonesia?

46. Socio-Economic aspects of brackish water aquaculture (Tambak) production in Nanggroe Aceh Darrusalam.

47. Farmer livelihoods in the humid forest and moist savannah zones of Cameroon.

48. Domestication, genre et vulnérabilité : Participation des femmes, des Jeunes et des catégories les plus pauvres à la domestication des arbres agroforestiers au Cameroun.

49. Land tenure and management in the districts around Mt Elgon: An assessment presented to the Mt Elgon ecosystem conservation programme.

50. The production and marketing of leaf meal from fodder shrubs in Tanga, Tanzania: A pro-poor enterprise for improving livestock productivity.

51. Buyers Perspective on Environmental Services (ES) and Commoditization as an approach to liberate ES markets in the Philippines. 
52. Towards Towards community-driven conservation in southwest China: Reconciling state and local perceptions.

53. Biofuels in China: An Analysis of the Opportunities and Challenges of Jatropha curcas in Southwest China.

54. Jatropha curcas biodiesel production in Kenya: Economics and potential value chain development for smallholder farmers

55. Livelihoods and Forest Resources in Aceh and Nias for a Sustainable Forest Resource Management and Economic Progress

56. Agroforestry on the interface of Orangutan Conservation and Sustainable Livelihoods in Batang Toru, North Sumatra.

2008

57. Assessing Hydrological Situation of Kapuas Hulu Basin, Kapuas Hulu Regency, West Kalimantan.

58. Assessing the Hydrological Situation of Talau Watershed, Belu Regency, East Nusa Tenggara.

59. Kajian Kondisi Hidrologis DAS Talau, Kabupaten Belu, Nusa Tenggara Timur.

60. Kajian Kondisi Hidrologis DAS Kapuas Hulu, Kabupaten Kapuas Hulu, Kalimantan Barat.

61. Lessons learned from community capacity building activities to support agroforest as sustainable economic alternatives in Batang Toru orang utan habitat conservation program (Martini, Endri et al.)

62. Mainstreaming Climate Change in the Philippines.

63. A Conjoint Analysis of Farmer Preferences for Community Forestry Contracts in the Sumber Jaya Watershed, Indonesia.

64. The highlands: a shared water tower in a changing climate and changing Asia

65. Eco-Certification: Can It Deliver Conservation and Development in the Tropics.

66. Designing ecological and biodiversity sampling strategies. Towards mainstreaming climate change in grassland management.

67. Towards mainstreaming climate change in grassland management policies and practices on the Tibetan Plateau

68. An Assessment of the Potential for Carbon Finance in Rangelands

69 ECA Trade-offs Among Ecosystem Services in the Lake Victoria Basin.

69. The last remnants of mega biodiversity in West Java and Banten: an in-depth exploration of RaTA (Rapid Land Tenure Assessment) in Mount Halimun-Salak National Park Indonesia

70. Le business plan d'une petite entreprise rurale de production et de commercialisation des plants des arbres locaux. Cas de quatre pépinières rurales au Cameroun.

71. Les unités de transformation des produits forestiers non ligneux alimentaires au Cameroun. Diagnostic technique et stratégie de développement Honoré Tabuna et Ingratia Kayitavu.

72. Les exportateurs camerounais de safou (Dacryodes edulis) sur le marché sous régional et international. Profil, fonctionnement et stratégies de développement.

73. Impact of the Southeast Asian Network for Agroforestry Education (SEANAFE) on agroforestry education capacity.

74. Setting landscape conservation targets and promoting them through compatible land use in the Philippines.

75. Review of methods for researching multistrata systems. 
76. Study on economical viability of Jatropha curcas L. plantations in Northern Tanzania assessing farmers' prospects via cost-benefit analysis

77. Cooperation in Agroforestry between Ministry of Forestry of Indonesia and International Center for Research in Agroforestry

78. "China's bioenergy future. an analysis through the Lens if Yunnan Province

79. Land tenure and agricultural productivity in Africa: A comparative analysis of the economics literature and recent policy strategies and reforms

80. Boundary organizations, objects and agents: linking knowledge with action in Agroforestry watersheds

81. Reducing emissions from deforestation and forest degradation (REDD) in Indonesia: options and challenges for fair and efficient payment distribution mechanisms

2009

82. Mainstreaming climate change into agricultural education: challenges and perspectives

83. Challenging conventional mindsets and disconnects in conservation: the emerging role of ecoagriculture in Kenya's landscape mosaics

84. Lesson learned RATA garut dan bengkunat: suatu upaya membedah kebijakan pelepasan kawasan hutan dan redistribusi tanah bekas kawasan hutan

85. The emergence of forest land redistribution in Indonesia

86. Commercial opportunities for fruit in Malawi

87. Status of fruit production processing and marketing in Malawi

88. Fraud in tree science

89. Trees on farm: analysis of global extent and geographical patterns of agroforestry

90. The springs of Nyando: water, social organization and livelihoods in Western Kenya

91. Building capacity toward region-wide curriculum and teaching materials development in agroforestry education in Southeast Asia

92. Overview of biomass energy technology in rural Yunnan (Chinese - English abstract)

93. A pro-growth pathway for reducing net GHG emissions in China

94. Analysis of local livelihoods from past to present in the central Kalimantan Ex-Mega Rice Project area

95. Constraints and options to enhancing production of high quality feeds in dairy production in Kenya, Uganda and Rwanda

2010

96. Agroforestry education in the Philippines: status report from the Southeast Asian Network for Agroforestry Education (SEANAFE)

97. Economic viability of Jatropha curcas L. plantations in Northern Tanzania- assessing farmers' prospects via cost-benefit analysis.

98. Hot spot of emission and confusion: land tenure insecurity, contested policies and competing claims in the central Kalimantan Ex-Mega Rice Project area

99. Agroforestry competences and human resources needs in the Philippines

100. CES/COS/CIS paradigms for compensation and rewards to enhance environmental Services 
101. Case study approach to region-wide curriculum and teaching materials development in agroforestry education in Southeast Asia

102. Stewardship agreement to reduce emissions from deforestation and degradation (REDD): Lubuk Beringin's Hutan Desa as the first village forest in Indonesia

103. Landscape dynamics over time and space from ecological perspective

104. Komoditisasi atau koinvestasi jasa lingkungan: skema imbal jasa lingkungan program peduli sungai di DAS Way Besai, Lampung, Indonesia

105. Improving smallholders' rubber quality in Lubuk Beringin, Bungo district, Jambi province, Indonesia: an initial analysis of the financial and social benefits

106. Rapid Carbon Stock Appraisal (RACSA) in Kalahan, Nueva Vizcaya, Philippines

107. Tree domestication by ICRAF and partners in the Peruvian Amazon: lessons learned and future prospects in the domain of the Amazon Initiative eco-regional program

108. Memorias del Taller Nacional: "Iniciativas para Reducir la Deforestación en la region Andino Amazónica", 09 de Abril del 2010. Proyecto REALU Peru

109. Percepciones sobre la Equidad y Eficiencia en la cadena de valor de REDD en Perú -Reporte de Talleres en Ucayali, San Martín y Loreto, 2009. Proyecto REALU-Perú.

110. Reducción de emisiones de todos los Usos del Suelo. Reporte del Proyecto REALU Perú Fase 1

111. Programa Alternativas a la Tumba-y-Quema (ASB) en el Perú. Informe Resumen y Síntesis de la Fase II. 2da. versión revisada

112. Estudio de las cadenas de abastecimiento de germoplasma forestal en la amazonía Boliviana

113. Biodiesel in the Amazon

114. Estudio de mercado de semillas forestales en la amazonía Colombiana

115. Estudio de las cadenas de abastecimiento de germoplasma forestal en Ecuador http://dx.doi.org10.5716/WP10340.PDF

116. How can systems thinking, social capital and social network analysis help programs achieve impact at scale?

117. Energy policies, forests and local communities in the Ucayali Region, Peruvian Amazon

118. NTFPs as a Source of Livelihood Diversification for Local Communities in the Batang Toru Orangutan Conservation Program

119. Studi Biodiversitas: Apakah agroforestry mampu mengkonservasi keanekaragaman hayati di DAS Konto?

120. Estimasi Karbon Tersimpan di Lahan-lahan Pertanian di DAS Konto, Jawa Timur

121. Implementasi Kaji Cepat Hidrologi (RHA) di Hulu DAS Brantas, Jawa Timur. http://dx.doi.org/10.5716/WP10338.PDF

122. Kaji Cepat Hidrologi di Daerah Aliran Sungai Krueng Peusangan, NAD,Sumatra http://dx.doi.org/10.5716/WP10337.PDF

123. A Study of Rapid Hydrological Appraisal in the Krueng Peusangan Watershed, NAD, Sumatra. http://dx.doi.org/10.5716/WP10339.PDF

2011

124. An Assessment of farm timber value chains in Mt Kenya area, Kenya

125. A Comparative financial analysis of current land use systems and implications for the adoption of improved agroforestry in the East Usambaras, Tanzania

126. Agricultural monitoring and evaluation systems 
127. Challenges and opportunities for collaborative landscape governance in the East Usambara Mountains, Tanzania

128. Transforming Knowledge to Enhance Integrated Natural Resource Management Research, Development and Advocacy in the Highlands of Eastern Africa http://dx.doi.org/10.5716/WP11084.PDF

129. Carbon-forestry projects in the Philippines: potential and challenges The Mt Kitanglad Range forest-carbon development http://dx.doi.org10.5716/WP11054.PDF

130. Carbon forestry projects in the Philippines: potential and challenges. The Arakan Forest Corridor forest-carbon project. http://dx.doi.org10.5716/WP11055.PDF

131. Carbon-forestry projects in the Philippines: potential and challenges. The Laguna Lake Development Authority's forest-carbon development project. http://dx.doi.org/10.5716/WP11056.PDF

132. Carbon-forestry projects in the Philippines: potential and challenges. The Quirino forest-carbon development project in Sierra Madre Biodiversity Corridor http://dx.doi.org10.5716/WP11057.PDF

133. Carbon-forestry projects in the Philippines: potential and challenges. The Ikalahan Ancestral Domain forest-carbon development http://dx.doi.org10.5716/WP11058.PDF

134. The Importance of Local Traditional Institutions in the Management of Natural Resources in the Highlands of Eastern Africa. http://dx.doi.org/10.5716/WP11085.PDF

135. Socio-economic assessment of irrigation pilot projects in Rwanda. http://dx.doi.org/10.5716/WP11086.PDF

136. Performance of three rambutan varieties (Nephelium lappaceum L.) on various nursery media. http://dx.doi.org/10.5716/WP11232.PDF

137. Climate change adaptation and social protection in agroforestry systems: enhancing adaptive capacity and minimizing risk of drought in Zambia and Honduras http://dx.doi.org/10.5716/WP11269.PDF

138. Does value chain development contribute to rural poverty reduction? Evidence of asset building by smallholder coffee producers in Nicaragua http://dx.doi.org/10.5716/WP11271.PDF

139. Potential for biofuel feedstock in Kenya. http://dx.doi.org/10.5716/WP11272.PDF

140. Impact of fertilizer trees on maize production and food security in six districts of Malawi. http://dx.doi.org/10.5716/WP11281.PDF

2012

141. Fortalecimiento de capacidades para la gestión del Santuario Nacional Pampa Hermosa: Construyendo las bases para un manejo adaptativo para el desarrollo local. Memorias del Proyecto. http://dx.doi.org/10.5716/WP12005.PDF

142. Understanding rural institutional strengthening: A cross-level policy and institutional framework for sustainable development in Kenya http://dx.doi.org/10.5716/WP12012.PDF

143. Climate change vulnerability of agroforestry http://dx.doi.org/10.5716/WP16722.PDF

144. Rapid assesment of the inner Niger delta of Mali http://dx.doi.org/10.5716/WP12021.PDF

145. Designing an incentive program to reduce on-farm deforestationin the East Usambara Mountains, Tanzania http://dx.doi.org/10.5716/WP12048.PDF

146. Extent of adoption of conservation agriculture and agroforestry in Africa: the case of Tanzania, Kenya, Ghana, and Zambia http://dx.doi.org/10.5716/WP12049.PDF 
147. Policy incentives for scaling up conservation agriculture with trees in Africa: the case of Tanzania, Kenya, Ghana and Zambia http://dx.doi.org/10.5716/WP12050.PDF

148. Commoditized or co-invested environmental services? Rewards for environmental services scheme: River Care program Way Besai watershed, Lampung, Indonesia. http://dx.doi.org/10.5716/WP12051.PDF

149. Assessment of the headwaters of the Blue Nile in Ethiopia. http://dx.doi.org/10.5716/WP12160.PDF

150. Assessment of the uThukela Watershed, Kwazaulu. http://dx.doi.org/10.5716/WP12161.PDF

151. Assessment of the Oum Zessar Watershed of Tunisia. http://dx.doi.org/10.5716/WP12162.PDF

152. Assessment of the Ruwenzori Mountains in Uganda. http://dx.doi.org/10.5716/WP12163.PDF

153. History of agroforestry research and development in Viet Nam. Analysis of research opportunities and gaps. http://dx.doi.org/10.5716/WP12052.PDF

154. REDD+ in Indonesia: a Historical Perspective. http://dx.doi.org/10.5716/WP12053.PDF

155. Agroforestry and Forestry in Sulawesi series: Livelihood strategies and land use system dynamics in South Sulawesi http://dx.doi.org/10.5716/WP12054.PDF

156. Agroforestry and Forestry in Sulawesi series: Livelihood strategies and land use system dynamics in Southeast Sulawesi. http://dx.doi.org/10.5716/WP12055.PDF

157. Agroforestry and Forestry in Sulawesi series: Profitability and land-use systems in South and Southeast Sulawesi. http://dx.doi.org/10.5716/WP12056.PDF

158. Agroforestry and Forestry in Sulawesi series: Gender, livelihoods and land in South and Southeast Sulawesi http://dx.doi.org/10.5716/WP12057.PDF

159. Agroforestry and Forestry in Sulawesi series: Agroforestry extension needs at the community level in AgFor project sites in South and Southeast Sulawesi, Indonesia. http://dx.doi.org/10.5716/WP12058.PDF

160. Agroforestry and Forestry in Sulawesi series: Rapid market appraisal of agricultural, plantation and forestry commodities in South and Southeast Sulawesi. http://dx.doi.org/10.5716/WP12059.PDF

2013

161. Diagnosis of farming systems in the Agroforestry for Livelihoods of Smallholder farmers in Northwestern Viet Nam project http://dx.doi.org/10.5716/WP13033.PDF

162. Ecosystem vulnerability to climate change: a literature review. http://dx.doi.org/10.5716/WP13034.PDF

163. Local capacity for implementing payments for environmental services schemes: lessons from the RUPES project in northeastern Viet Nam http://dx.doi.org/10.5716/WP13046.PDF

164. Seri Agroforestri dan Kehutanan di Sulawesi: Agroforestry dan Kehutanan di Sulawesi: Strategi mata pencaharian dan dinamika sistem penggunaan lahan di Sulawesi Selatan http://dx.doi.org/10.5716/WP13040.PDF

165. Seri Agroforestri dan Kehutanan di Sulawesi: Mata pencaharian dan dinamika sistem penggunaan lahan di Sulawesi Tenggara http://dx.doi.org/10.5716/WP13041.PDF

166. Seri Agroforestri dan Kehutanan di Sulawesi: Profitabilitas sistem penggunaan lahan di Sulawesi Selatan dan Sulawesi Tenggara http://dx.doi.org/10.5716/WP13042.PDF

167. Seri Agroforestri dan Kehutanan di Sulawesi: Gender, mata pencarian dan lahan di Sulawesi Selatan dan Sulawesi Tenggara http://dx.doi.org/10.5716/WP13043.PDF 
168. Seri Agroforestri dan Kehutanan di Sulawesi: Kebutuhan penyuluhan agroforestri pada tingkat masyarakat di lokasi proyek AgFor di Sulawesi Selatan dan Tenggara, Indonesia. http://dx.doi.org/10.5716/WP13044.PDF

169. Seri Agroforestri dan Kehutanan di Sulawesi: Laporan hasil penilaian cepat untuk komoditas pertanian, perkebunan dan kehutanan di Sulawesi Selatan dan Tenggara http://dx.doi.org/10.5716/WP13045.PDF

170. Agroforestry, food and nutritional security http://dx.doi.org/10.5716/WP13054.PDF

171. Stakeholder Preferences over Rewards for Ecosystem Services: Implications for a REDD+ Benefit Distribution System in Viet Nam http://dx.doi.org/10.5716/WP13057.PDF

172. Payments for ecosystem services schemes: project-level insights on benefits for ecosystems and the rural poor http://dx.doi.org/10.5716/WP13001.PDF

173. Good practices for smallholder teak plantations: keys to success http://dx.doi.org/10.5716/WP13246.PDF

174. Market analysis of selected agroforestry products in the Vision for Change Project intervention Zone, Côte d'Ivoire http://dx.doi.org/10.5716/WP13249.PDF

175. Rattan futures in Katingan: why do smallholders abandon or keep their gardens in Indonesia's 'rattan district'? http://dx.doi.org/10.5716/WP13251.PDF

176. Management along a gradient: the case of Southeast Sulawesi's cacao production landscapes http://dx.doi.org/10.5716/WP13265.PDF

2014

177. Are trees buffering ecosystems and livelihoods in agricultural landscapes of the Lower Mekong Basin? Consequences for climate-change adaptation. http://dx.doi.org/10.5716/WP14047.PDF

178. Agroforestry, livestock, fodder production and climate change adaptation and mitigation in East Africa: issues and options. http://dx.doi.org/10.5716/WP14050.PDF

179. Trees on farms: an update and reanalysis of agroforestry's global extent and socio-ecological characteristics. http://dx.doi.org/10.5716/WP14064.PDF

180. Beyond reforestation: an assessment of Vietnam's REDD+ readiness. http://dx.doi.org/10.5716/WP14097.PDF

181. Farmer-to-farmer extension in Kenya: the perspectives of organizations using the approach. http://dx.doi.org/10.5716/WP14380.PDF

182. Farmer-to-farmer extension in Cameroon: a survey of extension organizations. http://dx.doi.org/10.5716/WP14383.PDF

183. Farmer-to-farmer extension approach in Malawi: a survey of organizations: a survey of organizations http://dx.doi.org/10.5716/WP14391.PDF

184. Seri Agroforestri dan Kehutanan di Sulawesi: Kuantifikasi jasa lingkungan air dan karbon pola agroforestri pada hutan rakyat di wilayah sungai Jeneberang

185. Options for Climate-Smart Agriculture at Kaptumo Site in Kenyahttp://dx.doi.org/10.5716/WP14394.PDF

2015

186. Agroforestry for Landscape Restoration and Livelihood Development in Central Asia http://dx.doi.org/10.5716/WP14143.PDF 
187. "Projected Climate Change and Impact on Bioclimatic Conditions in the Central and SouthCentral Asia Region" http://dx.doi.org/10.5716/WP14144.PDF

188. Land Cover Changes, Forest Loss and Degradation in Kutai Barat, Indonesia. http://dx.doi.org/10.5716/WP14145.PDF

189. The Farmer-to-Farmer Extension Approach in Malawi: A Survey of Lead Farmers. http://dx.doi.org/10.5716/WP14152.PDF

190. Evaluating indicators of land degradation and targeting agroforestry interventions in smallholder farming systems in Ethiopia. http://dx.doi.org/10.5716/WP14252.PDF

191. Land health surveillance for identifying land constraints and targeting land management options in smallholder farming systems in Western Cameroon

192. Land health surveillance in four agroecologies in Malawi

193. Cocoa Land Health Surveillance: an evidence-based approach to sustainable management of cocoa landscapes in the Nawa region, South-West Côte d'Ivoire http://dx.doi.org/10.5716/WP14255.PDF

194. Situational analysis report: Xishuangbanna autonomous Dai Prefecture, Yunnan Province, China. http://dx.doi.org/10.5716/WP14255.PDF

195. Farmer-to-farmer extension: a survey of lead farmers in Cameroon. http://dx.doi.org/10.5716/WP15009.PDF

196. From transition fuel to viable energy source Improving sustainability in the sub-Saharan charcoal sector http://dx.doi.org/10.5716/WP15011.PDF

197. Mobilizing Hybrid Knowledge for More Effective Water Governance in the Asian Highlands http://dx.doi.org/10.5716/WP15012.PDF

198. Water Governance in the Asian Highlands http://dx.doi.org/10.5716/WP15013.PDF

199. Assessing the Effectiveness of the Volunteer Farmer Trainer Approach in Dissemination of Livestock Feed Technologies in Kenya vis-à-vis other Information Sources http://dx.doi.org/10.5716/WP15022.PDF

200. The rooted pedon in a dynamic multifunctional landscape: Soil science at the World Agroforestry Centre http://dx.doi.org/10.5716/WP15023.PDF

201. Characterising agro-ecological zones with local knowledge. Case study: Huong Khe district, $\mathrm{Ha}$ Tinh, Viet Nam http://dx.doi.org/10.5716/WP15050.PDF

202. Looking back to look ahead: Insight into the effectiveness and efficiency of selected advisory approaches in the dissemination of agricultural technologies indicative of Conservation Agriculture with Trees in Machakos County, Kenya. http://dx.doi.org/10.5716/WP15065.PDF

203. Pro-poor Biocarbon Projects in Eastern Africa Economic and Institutional Lessons. http://dx.doi.org/10.5716/WP15022.PDF

204. Projected climate change impacts on climatic suitability and geographical distribution of banana and coffee plantations in Nepal. http://dx.doi.org/10.5716/WP15294.PDF

205. Agroforestry and Forestry in Sulawesi series: Smallholders' coffee production and marketing in Indonesia. A case study of two villages in South Sulawesi Province. http://dx.doi.org/10.5716/WP15690.PDF

206. Mobile phone ownership and use of short message service by farmer trainers: a case study of Olkalou and Kaptumo in Kenya http://dx.doi.org/10.5716/WP15691.PDF

207. Associating multivariate climatic descriptors with cereal yields: a case study of Southern Burkina Faso http://dx.doi.org/10.5716/WP15273.PDF

208. Preferences and adoption of livestock feed practices among farmers in dairy management groups in Kenya http://dx.doi.org/10.5716/WP15675.PDF 
209. Scaling up climate-smart agriculture: lessons learned from South Asia and pathways for success http://dx.doi.org/10.5716/WP15720.PDF

210. Agroforestry and Forestry in Sulawesi series: Local perceptions of forest ecosystem services and collaborative formulation of reward mechanisms in South and Southeast Sulawesi http://dx.doi.org/10.5716/WP15721.PDF

211. Potential and challenges in implementing the co-investment of ecosystem services scheme in Buol District, Indonesia. http://dx.doi.org/10.5716/WP15722.PDF

212. Tree diversity and its utilization by the local community in Buol District, Indonesia http://dx.doi.org/10.5716/WP15723.PDF

213 Vulnerability of smallholder farmers and their preferences on farming practices in Buol District, Indonesia http://dx.doi.org/10.5716/WP15724.PDF

214. Dynamics of Land Use/Cover Change and Carbon Emission in Buol District, Indonesia http://dx.doi.org/10.5716/WP15725.PDF

215. Gender perspective in smallholder farming practices in Lantapan, Phillippines. http://dx.doi.org/10.5716/WP15726.PDF

216. Vulnerability of smallholder farmers in Lantapan, Bukidnon. http://dx.doi.org/10.5716/WP15727.PDF

217. Vulnerability and adaptive capacity of smallholder farmers in Ho Ho Sub-watershed, Ha Tinh Province, Vietnam http://dx.doi.org/10.5716/WP15728.PDF

218. Local Knowledge on the role of trees to enhance livelihoods and ecosystem services in northern central Vietnam http://dx.doi.org/10.5716/WP15729.PDF

219. Land-use/cover change in Ho Ho Sub-watershed, Ha Tinh Province, Vietnam. http://dx.doi.org/10.5716/WP15730.PDF

2016

220. Agroforestry and Forestry in Sulawesi series: Evaluation of the Agroforestry Farmer Field Schools on agroforestry management in South and Southeast Sulawesi, Indonesia. http://dx.doi.org/10.5716/WP16002.PDF

221. Farmer-to-farmer extension of livestock feed technologies in Rwanda: A survey of volunteer farmer trainers and organizations. http://dx.doi.org/10.5716/WP16005.PDF

222. Projected Climate Change Impact on Hydrology, Bioclimatic Conditions, and Terrestrial Ecosystems in the Asian Highlands http://dx.doi.org/10.5716/WP16006.PDF

223. Adoption of Agroforestry and its impact on household food security among farmers in Malawi http://dx.doi.org/10.5716/WP16013.PDF

224. Agroforestry and Forestry in Sulawesi series: Information channels for disseminating innovative agroforestry practices to villages in Southern Sulawesi, Indonesia http://dx.doi.org/10.5716/WP16034.PDF

225. Agroforestry and Forestry in Sulawesi series: Unravelling rural migration networks.Landtenure arrangements among Bugis migrant communities in Southeast Sulawesi. http://dx.doi.org/10.5716/WP16035.PDF

226. Agroforestry and Forestry in Sulawesi series: Women's participation in agroforestry: more benefit or burden? A gendered analysis of Gorontalo Province. http://dx.doi.org/10.5716/WP16036.PDF

227. Kajian Kelayakan dan Pengembangan Desain Teknis Rehabilitasi Pesisir di Sulawesi Tengah. http://dx.doi.org/10.5716/WP16037.PDF

228. Selection of son tra clones in North West Vietnam. http://dx.doi.org/10.5716/WP16038.PDF 
229. Growth and fruit yield of seedlings, cuttings and grafts from selected son tra trees in Northwest Vietnam http://dx.doi.org/10.5716/WP16046.PDF

230. Gender-Focused Analysis of Poverty and Vulnerability in Yunnan, China http://dx.doi.org/10.5716/WP16071.PDF

231. Seri Agroforestri dan Kehutanan di Sulawesi: Kebutuhan Penyuluhan Agroforestri untuk Rehabilitasi Lahan di Sumba Timur, Nusa Tenggara Timur, Indonesia. http://dx.doi.org/10.5716/WP16077.PDF

232. Agroforestry and Forestry in Sulawesi series: Agroforestry extension needs for land rehabilitation in East Sumba, East Nusa Tenggara, Indonesia. http://dx.doi.org/10.5716/WP16078.PDF

233. Central hypotheses for the third agroforestry paradigm within a common definition. http://dx.doi.org/10.5716/WP16079.PDF

234. Assessing smallholder farmers' interest in shade coffee trees: The Farming Systems of Smallholder Coffee Producers in the Gisenyi Area, Rwanda: a participatory diagnostic study. http://dx.doi.org/10.5716/WP16104.PDF

235. Review of agricultural market information systems in |sub-Saharan Africa. http://dx.doi.org/10.5716/WP16110.PDF

236. Vision and road map for establishment of a protected area in Lag Badana, Lower Jubba, Somalia. http://dx.doi.org/10.5716/WP16127.PDF

237. Replicable tools and frameworks for Bio-Carbon Development in West Africa. http://dx.doi.org/10.5716/WP16138.PDF

238. Existing Conditions, Challenges and Needs in the Implementation of Forestry and Agroforestry Extension in Indonesia. http://dx.doi.org/10.5716/WP16141.PDF

239. Situasi Terkini, Tantangan dan Kebutuhan Pelaksanaan Penyuluhan Kehutanan dan Agroforestri di Indonesia. http://dx.doi.org/10.5716/WP16142.PDF

240. The national agroforestry policy of India: experiential learning in development and delivery phases. http://dx.doi.org/10.5716/WP16143.PDF

241. Agroforestry and Forestry in Sulawesi series: Livelihood strategies and land-use system dynamics in Gorontalo. http://dx.doi.org/10.5716/WP16157.PDF

242. Seri Agroforestri dan Kehutanan di Sulawesi: Strategi mata pencaharian dan dinamika sistem penggunaan lahan di Gorontalo. http://dx.doi.org/10.5716/WP16158.PDF

243. Ruang, Gender dan Kualitas Hidup Manusia: Sebuah studi Gender pada komunitas perantau dan pengelola kebun di Jawa Barat. http://dx.doi.org/10.5716/WP16159.PDF

244. Gendered Knowledge and perception in managing grassland areas in East Sumba, Indonesia. http://dx.doi.org/10.5716/WP16160.PDF

245. Pengetahuan dan persepsi masyarakat pengelola padang aavana, Sebuah Kajian Gender di Sumba Timur. http://dx.doi.org/10.5716/WP16161.PDF

246. Dinamika Pengambilan Keputusan pada komunitas perantau dan pengelola kebun di Jawa Barat. http://dx.doi.org/10.5716/WP16162.PDF

247. Gaharu (eaglewood) domestication: Biotechnology, markets and agroforestry options. http://dx.doi.org/10.5716/WP16163.PDF

248. Marine habitats of the Lamu-Kiunga coast: an assessment of biodiversity value, threats and opportunities. http://dx.doi.org/10.5716/WP16167.PDF

249. Assessment of the biodiversity in terrestrial landscapes of the Witu protected area and surroundings, Lamu County Kenya. http://dx.doi.org/10.5716/WP16172.PDF

250. An ecosystem services perspective on benefits that people derive from biodiversity of Coastal forests in Lamu County, Kenya http://dx.doi.org/10.5716/WP16173.PDF 
251. Assessment of the biodiversity in terrestrial and marine landscapes of the proposed Laga Badana National Park and surrounding areas, Jubaland, Somalia.

http://dx.doi.org/10.5716/WP16174.PDF

2017

252. Preferensi Petani terhadap Topik Penyuluhan dan Penyebaran Informasi Agroforestri di Indonesia. http://dx.doi.org/10.5716/WP16181.PDF

253. Seri Agroforestri dan Kehutanan di Sulawesi: Keanekaragaman hayati jenis pohon pada hutan rakyat agroforestri di DAS Balangtieng, Sulawesi Selatan. http://dx.doi.org/10.5716/WP16182.PDF

254. Potensi dan Tantangan dalam Pengembangan Skema Ko-Investasi Jasa Lingkungan di Kabupaten Buol, Indonesia. http://dx.doi.org/10.5716/WP17008.PDF

255. Keragaman Jenis Pohon dan Pemanfaatannya oleh Masyarakat di Kabupaten Buol, Indonesia. http://dx.doi.org/10.5716/WP17009.PDF

256. Kerentanan dan preferensi sistem pertanian petani di Kabupaten Buol, Indonesia. http://dx.doi.org/10.5716/WP17010.PDF

257. Dinamika Perubahan Penggunaan/Tutupan Lahan Serta Cadangan Karbon di Kabupaten Buol, Indonesia. http://dx.doi.org/10.5716/WP17011.PDF

258. The Effectiveness of the Volunteer Farmer Trainer Approach vis-à-vis Other Information Sources in Dissemination of Livestock Feed Technologies in Uganda.

http://dx.doi.org/10.5716/WP17104.PDF

259. Agroforestry and Forestry in Sulawesi series: Impact of agricultural-extension booklets on community livelihoods in South and Southeast Sulawesi. http://dx.doi.org/10.5716/WP17125.PDF

260. Petani Menjadi Penyuluh, Mungkinkah? Sebuah Pendekatan Penyuluhan dari Petani ke Petani di Kabupaten Sumba Timur. http://dx.doi.org/10.5716/WP17145.PDF

261. Dampak Perubahan Tutupan Lahan terhadap Kondisi Hidrologi di Das Buol, Kabupaten Buol, Sulawesi Tengah: Simulasi dengan Model Genriver. http://dx.doi.org/10.5716/WP17146.PDF

262. Analisis Tapak Mata Air Umbulan, Pasuruan, Jawa Timur. Kajian elemen biofisik dan persepsi masyarakat. http://dx.doi.org/10.5716/WP17147.PDF

263. Planned comparisons demystified. http://dx.doi.org/10.5716/WP17354.PDF

264. Soil health decision support for NERC digital soil platforms: A survey report. http://dx.doi.org/10.5716/WP17355.PDF

265. Seri Pembangunan Ekonomi Pedesaan Indonesia: Menanam di bukit gundul: Pengetahuan masyarakat lokal dalam upaya restorasi lahan di Sumba

Timur. http://dx.doi.org/10.5716/WP17356.PDF

266. Tree diversity and carbon stock in three districts of Kutai Timur, Pasir and Berau, East Kalimantan http://dx.doi.org/10.5716/WP17357.PDF

267. Tree Diversity and Carbon Stock in Various Land Use Systems of Banyuasin and Musi Banyuasin Districts, South Sumatera http://dx.doi.org/10.5716/WP17358.PDF

268. Tree diversity and carbon stock in various land cover systems of Jayapura, Jayawijaya and Merauke Districts, Papua Province http://dx.doi.org/10.5716/WP17359.PDF

269. Modelling tree production based on farmers' knowledge: case for kapok (Ceiba pentandra) and candlenut (Aleurites mollucana) under various agroforestry scenarios.

http://dx.doi.org/10.5716/WP17361.PDF 
270. The Impact of Land Cover and Climate Change on Present and Future Watershed Condition. Study case: Tugasan, Alanib and Kulasihan Sub-watershed of Manupali Watershed, Lantapan, Bukidnon, Philippines. http://dx.doi.org/10.5716/WP17362.PDF

271. Tree Diversity and Above-ground Carbon Stock estimation in Various Land use Systems in Banjarnegara, Banyumas and Purbalingga, Central Java. http://dx.doi.org/10.5716/WP17363.PDF

272. Agroforestry and Forestry in Sulawesi series: Landscape Management Strategies in Sulawesi: Review of Intervention Options. http://dx.doi.org/10.5716/WP17364.PDF

273. Household Food-Security and Nutritional Status of Women and Children in Buol Regency, Central Sulawesi, Indonesia. http://dx.doi.org/10.5716/WP17365.PDF

274 Palm oil expansion in tropical forest margins or sustainability of production? Focal issues of regulations and private standards. http://dx.doi.org/10.5716/WP17366.PDF

2018

275 Decision analysis methods guide: agricultural policy for nutrition http://dx.doi.org/10.5716/WP18001.PDF

276 Supporting human nutrition in Africa through the integration of new and orphan crops into food systems: Placing the work of the African Orphan Crops Consortium in context. http://dx.doi.org/10.5716/WP18003.PDF

277 Seri Pembangunan Ekonomi Pedesaan Indonesia. Pilihan Manajemen Budidaya Kacang Tanah sebagai Upaya untuk Memperbaiki Penghidupan Masyarakat Haharu. http://dx.doi.org/10.5716/WP18004.PDF

278 Estudio de línea de base CCAFS a nivel de hogar en Nicaragua y Costa Rica. Fase de diagnóstico del estudio: "Contribución de la diversidad arbórea a los medios de vida para la adaptación y la mitigación al cambio climático. http://dx.doi.org/10.5716/WP18005.PDF

279 Understanding tree cover transition, drivers and stakeholder perspectives for effective landscape governance. A case study in Na Nhan commune, Dien Bien province, Vietnam. http://dx.doi.org/10.5716/WP18006.PDF

280 El Sistema "Quesungual": Agroforestería y manejo de suelos para la producción de maíz y frijol en laderas. http://dx.doi.org/10.5716/WP18007.PDF

281 Probabilistic Decision Modelling to Determine Impacts on Natural Resource Management and Livelihood Resilience in Marsabit County, Kenya. http://dx.doi.org/10.5716/WP18008.PDF

282 Shifting discourse, shifting power: how is climate change mitigation and justice negotiated in Indonesia? http://dx.doi.org/10.5716/WP18009.PDF

283 Result of Land Use Planning and Land Administration (LULA) Implementation in South Sumatra, East Kalimantan, Central Java and Papua. http://dx.doi.org/10.5716/WP18010.PDF 

The World Agroforestry Centre is an autonomous, non-profit research organization whose vision is a rural transformation in the developing world as smallholder households increase their use of trees in agricultural landscapes to improve food security, nutrition, income, health, shelter, social cohesion, energy resources and environmental sustainability. The Centre generates science-based knowledge about the diverse roles that trees play in agricultural landscapes, and uses its research to advance policies and practices, and their implementation that benefit the poor and the environment. It aims to ensure that all this is achieved by enhancing the quality of its science work, increasing operational efficiency, building and maintaining strong partnerships, accelerating the use and impact of its research, and promoting greater cohesion, interdependence and alignment within the organization.

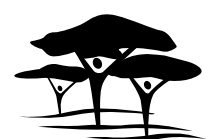

United Nations Avenue, Gigiri • PO Box 30677 • Nairobi, $00100 \cdot$ Kenya Telephone: +254 207224000 or via USA +1 6508336645 Fax: +254207224001 or via USA +1 6508336646

Email: worldagroforestry@cgiar.org•www.worldagroforestry.org

Southeast Asia Regional Program • Sindang Barang • Bogor 16680

PO Box $161 \cdot$ Bogor $16001 \cdot$ Indonesia

Telephone: +62 2518625415 • Fax: +62 2518625416

- Email: icraf-indonesia@cgiar.org

www.worldagroforestry.org/region/southeast-asia

blog.worldagroforestry.org 